\title{
Antiangiogenic Phytochemicals Constituent of Diet as Promising Candidates for Chemoprevention of Cancer
}

\author{
Ana Dácil Marrero ${ }^{1}$, Ana R. Quesada ${ }^{1,2}$, Beatriz Martínez-Poveda ${ }^{1,3, *(\mathbb{C})}$ and Miguel Ángel Medina $1,2, *$ (D) \\ 1 Department of Molecular Biology and Biochemistry, Faculty of Sciences, University of Málaga, \\ Andalucía Tech, and IBIMA, E-29071 Málaga, Spain; anadacil95@uma.es (A.D.M.); quesada@uma.es (A.R.Q.) \\ 2 Unidad 741 de CIBER “de Enfermedades Raras”, E-29071 Málaga, Spain \\ 3 CIBER de Enfermedades Cardiovasculares (CIBERCV), E-28019 Madrid, Spain \\ * Correspondence: bmpoveda@uma.es (B.M.-P.); medina@uma.es (M.Á.M.)
}

Citation: Marrero, A.D.; Quesada, A.R.; Martínez-Poveda, B.; Medina, M.Á. Antiangiogenic Phytochemicals Constituent of Diet as Promising Candidates for Chemoprevention of Cancer. Antioxidants 2022, 11, 302. https://doi.org/10.3390/ antiox11020302

Academic Editor: Stanley Omaye

Received: 29 December 2021

Accepted: 29 January 2022

Published: 31 January 2022

Publisher's Note: MDPI stays neutral with regard to jurisdictional claims in published maps and institutional affiliations.

Copyright: (C) 2022 by the authors. Licensee MDPI, Basel, Switzerland. This article is an open access article distributed under the terms and conditions of the Creative Commons Attribution (CC BY) license (https:// creativecommons.org/licenses/by/ $4.0 /)$.

\begin{abstract}
Despite the extensive knowledge on cancer nature acquired over the last years, the high incidence of this disease evidences a need for new approaches that complement the clinical intervention of tumors. Interestingly, many types of cancer are closely related to dietary habits associated with the Western lifestyle, such as low fruit and vegetable intake. Recent advances around the old-conceived term of chemoprevention highlight the important role of phytochemicals as good candidates for the prevention or treatment of cancer. The potential to inhibit angiogenesis exhibited by many natural compounds constituent of plant foods makes them especially interesting for their use as chemopreventive agents. Here, we review the antitumoral potential, with a focus on the antiangiogenic effects, of phenolic and polyphenolic compounds, such as quercetin or myricetin; terpenoids, such as ursolic acid or kahweol; and anthraquinones from Aloe vera, in different in vitro and in vivo assays, and the available clinical data. Although clinical trials have failed to assess the preventive role of many of these compounds, encouraging preclinical data support the efficacy of phytochemicals constituent of diet in the prevention and treatment of cancer, but a deeper understanding of their mechanisms of action and better designed clinical trials are urgently needed.
\end{abstract}

Keywords: cancer prevention; angiogenesis; chemoprevention; phytochemicals; bioactive compounds

\section{Introduction}

\subsection{Chemoprevention of Cancer}

Cancer is the second leading cause of death worldwide, just below cardiovascular diseases [1,2]. Interestingly, around a third of the deaths from cancer are due to the five leading behavioral and dietary risks: high body mass index, low fruit and vegetable intake, lack of physical activity, tobacco use, and alcohol use, features that are characteristic of a Western diet and lifestyle [3]. Two major approaches have been established to decrease cancer incidence and progression, namely, early detection and prevention of cancer [4-7]. In the last decades, there has been a focus on the chemoprevention of cancer, a concept first defined by Sporn in 1976 as the use of natural, synthetic, or biologic agents to reverse, suppress, or prevent tumor progression [8]. Whereas early detection of cancer is a broadly accepted approach, cancer chemoprevention still remains a matter of debate in the scientific community, mainly due to the heterogenic results obtained from the reported preventive interventions [9]. In this regard, the level at which the specific cancer preventive action is implemented, as well as the targeted population, must be considered [10] (Figure 1): (a) primary prevention, focused on decreasing the incidence of the disease in a broad population, mainly by reducing the exposure to carcinogenic factors; (b) secondary prevention, aimed at reducing the mortality from a particular type of cancer in medium/high-risk populations, with actions focused on early detection and treatment in subclinical stages of the disease; (c) tertiary prevention, targeted to cancer patients in more advanced stages of 
the disease and devoted to improving the survival rate and the quality of life. Due to the long-term nature of the preventive strategy, the chemopreventive agent should fulfill with some premises named minimal toxicity, low-cost price, and also capability to promote the physiological antitumor responses of the tumor microenvironment [11,12].

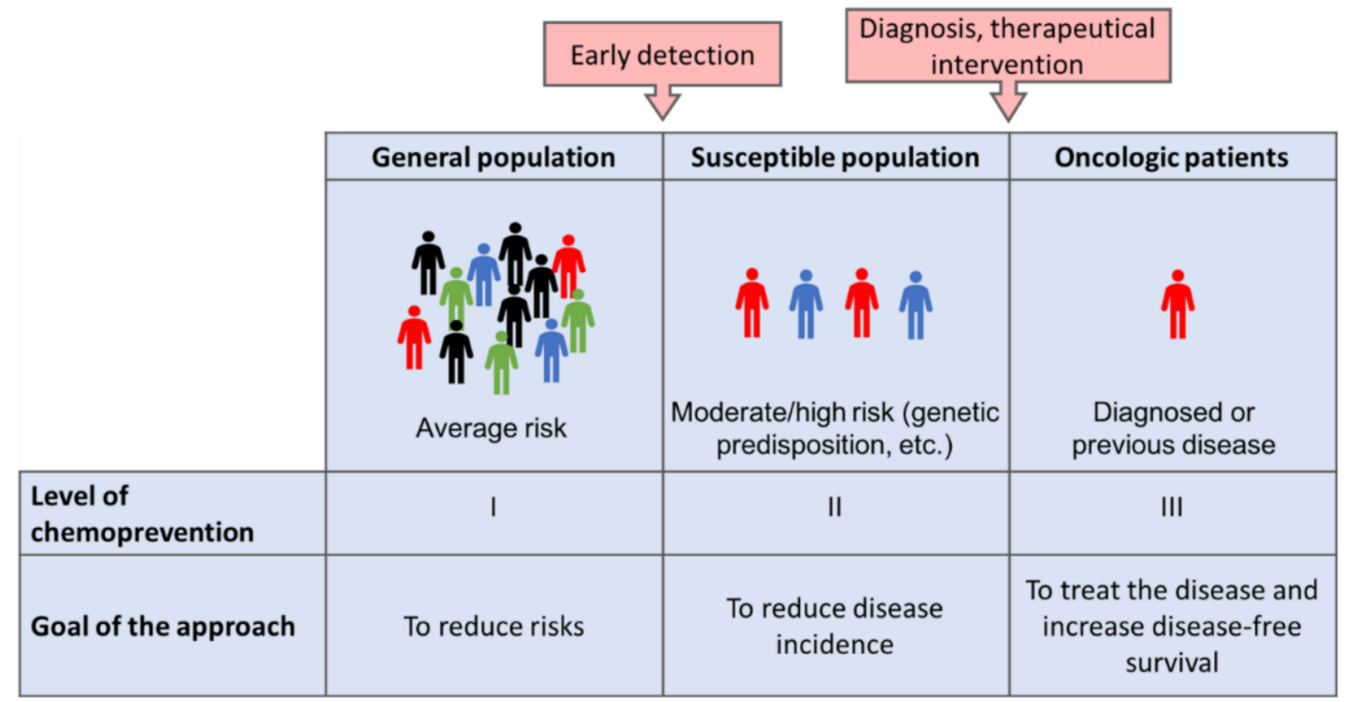

Figure 1. Levels of chemoprevention in cancer. The figure shows the three levels (I, II, III) at which a chemopreventive strategy can be implemented, and the different goals and targeted populations. (Level I of chemoprevention targets the general population, with the aim of reducing risks of developing cancer. Level II of chemoprevention faces the reduction in the incidence of the disease in moderate/high-risk patients who have, for instance, a genetic predisposition to develop a certain type of cancer. Level III of chemoprevention focuses on patients who are diagnosed or have recovered from previous cancer, with the objective of treating the disease and increasing disease-free survival). Modified from [12].

\subsection{Angiogenesis as a Target for Chemoprevention of Cancer}

In this review, we focus on angiogenesis, one of the hallmarks of cancer $[13,14]$ (Figure 2). Angiogenesis is the formation of new capillary blood vessels from pre-existing vascular plexus [15]. Despite its physiological role, deregulation of this process is associated with several pathologies, such as rheumatoid arthritis, diabetic retinopathy, and cancer $[16,17]$. Pathological activation of angiogenesis is a promising target for chemopreventive actions against cancer, since it supports the growth of the primary tumor by supplying it with nutrients and oxygen and promotes the metastatic process by providing an easy way out for tumor cells [15]. In this context, the concept of angioprevention emerges, referring to the prevention of cancer by inhibition and/or stabilization of tumor angiogenesis [11,15]. In line with this, plant-derived compounds are excellent angiopreventive candidates, since toxicities derived from their consumption are low or inexistent, they are easily accessible as they are components of dietary plant foods, and they exhibit pleiotropic biological activity that targets not only tumor cells, but also endothelial or immune cells. Indeed, targeting angiogenesis for cancer prevention using combinations of plant-derived compounds has been proposed as a feasible and promising anticancer approach [18].

In this review, we present some interesting plant-derived compounds contained in the diet, highlighting their potential to inhibit angiogenesis as a main chemopreventive feature. Table 1 summarizes some of the most used assays to study angiogenesis and/or new modulators of angiogenesis. 


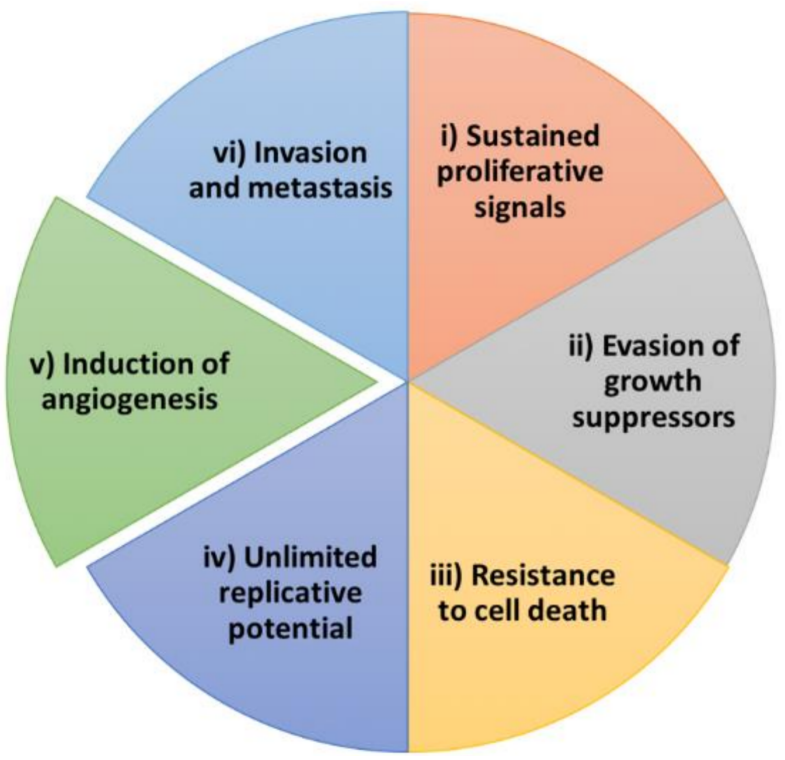

Figure 2. Hallmarks of cancer. The six hallmarks of cancer described by Hanahan and Weinberg in 2000 [13]. The issue was revisited in 2011 [14], when four new hallmarks (not shown in the figure) were added to the list. In 2022, the list of hallmarks has increased up to 14 [19].

Table 1. Some of the most used assays to study angiogenesis and/or new modulators of angiogenesis in vitro, ex vivo, and in vivo. EC: endothelial cells; MTT: 3-(4,5-dimethylthiazol-2-yl)-2,5diphenyltetrazolium bromide; ECM: extracellular matrix; MMP: matrix metalloproteinase; CAM: chorioallantoic membrane [20].

Assay

Proliferation/survival (MTT)

Tubular-like structure formation

In vitro

Migration/Invasion

Zymography (detection of gelatinase and caseinase activities)

Ex vivo

Mouse aortic ring

Chorioallantoic membrane

In vivo

Zebrafish intersegmental vessel models
Description

References

Angiogenesis depends directly on the active proliferation of EC. The MTT assay measures cellular viability based on the reduction of soluble MTT(3-(4,5-dimethylthiazol-2-yl)-2,5-diphenyltetrazolium bromide) to a blue-colored tetrazolium salt by mitochondrial reductases, followed by detection in a spectrophotometer.

Reorganization of EC to create tubular-like networks resembling blood vessel formation. Matrigel, a solubilized murine extract of basal lamina, is used as a substrate.

Migration throughout the ECM and its degradation are the main capacities for EC to form new vessels. The migration and invasion fluorometric assays are based on the disposal of fluorescence-labelled EC on a transwell system that allows the movement of EC towards chemotactic stimuli contained in the media in the well. Specific to the invasion assay, a thin layer of Matrigel is placed over the filter of the transwell. Afterward, the light emitted by fluorescence-labeled cells is measured.

Matrix metalloproteinases (MMPs) and serin proteases degrade the ECM to ease the rearrangement of EC to form new vessels. Finding inhibitors of these enzymes can limit the angiogenic process. The detection of their activity involves the electrophoresis of the secreted protease enzymes through discontinuous nondenaturing polyacrylamide gels containing enzyme's substrate (either type III gelatin or $\beta$-casein). Staining the gel with a protein dye allows the detection of the proteolytic activity as clear bands of lysis against a stained background.

Culture of transversal sections of rat aorta placed on Matrigel induces the outgrowth of the ring at day 7-14 that can be observed in the microscope. The strong blood irrigation of the chorioallantoic membrane makes it an economic, feasible model to study angiogenesis. Methylcellulose discs containing the studied compounds can be directly placed on the membrane to test their effect on embryonic angiogenesis.

Zebrafish is currently a model system for the study of angiogenesis during its embryonic development. After being treated with the compounds to test the circulatory system of the embryos (transparent) can be easily observed by microscopy or binocular scopes, and abnormalities in the development can be assessed. The detection can be improved by in situ hybridizations, among other approaches. 


\section{Plant-Derived Compounds Constituent of Diet with Antiangiogenic Activity}

\subsection{Phenolic and Polyphenolic Phytochemicals}

\subsubsection{Flavonols}

Flavonols are polyphenolic compounds belonging to the flavonoid subclass, mainly found in plant foods (fruits and vegetables). Different bioactive compounds of this family have been proposed to exert a chemopreventive activity in cancer, including quercetin, myricetin, kaempferol, and fisetin.

\section{Quercetin}

The bioactive flavonol quercetin (Figure 3a) is mainly found in onions, broccoli, several fruits, such as apples and berries, as well as in olive oil, red wine, and tea. The role of quercetin as a chemopreventive compound is based on its different antitumor reported effects [31], including cell cycle arrest, apoptosis induction or inhibition of antiapoptotic pathways, and inhibition of neutral sphingomyelinase in different cancer models [32-38]. In addition, the treatment with quercetin boosts the therapeutic effect of some anticancer drugs, revealing a promising role as a potential enhancer compound in chemotherapy [39]. Quercetin has been described as an antiangiogenic compound, targeting tumor-associated angiogenesis, both in vitro and in vivo. In endothelial cells, quercetin affects cell proliferation, migratory potential, tube formation capability, and matrix metalloproteinase (MMP)-2 expression [40] (Figure 4).

\section{Phenolic and polyphenolic phytochemicals}

(a)<smiles>O=c1c(O)c(-c2ccc(O)c(O)c2)oc2cc(O)cc(O)c12</smiles>

(b)<smiles>O=c1c(O)c(-c2cc(O)c(O)c(O)c2)oc2cc(O)cc(O)c12</smiles>

(c)<smiles>O=c1c(O)c(-c2ccc(O)cc2)oc2cc(O)cc(O)c12</smiles>

(d)<smiles>O=c1c(O)c(-c2ccc(O)c(O)c2)oc2cc(O)ccc12</smiles>

(e)<smiles>O=C(O[C@H]1Cc2c(O)cc(O)cc2O[C@H]1c1cc(O)c(O)c(O)c1)c1cc(O)c(O)c(O)c1</smiles>

(g)<smiles>Oc1ccc(/C=C/c2cc(O)cc(O)c2)cc1</smiles>

(h)<smiles>OCCc1ccc(O)c(O)c1</smiles>

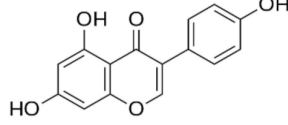

$\mathrm{OH}$ (1)<smiles>CC(C)c1cc2c(c(O)c1O)[C@@]13CCCC(C)(C)[C@@H]1CC2OC3=O</smiles>

Figure 3. Chemical structures of the phenolic and polyphenolic phytochemicals (a) quercetin, (b) myricetin, (c) kaempferol, (d) fisetin, (e) genistein, (f) epigallocatechin-3-gallate, (g) resveratrol, and (h) hydroxytyrosol; the terpenes (i) ursolic acid, (j) kahweol, (k) celastrol, (l) carnosol, and (m) carnosic acid; and the anthraquinones (n) emodin and (o) aloe-emodin. 


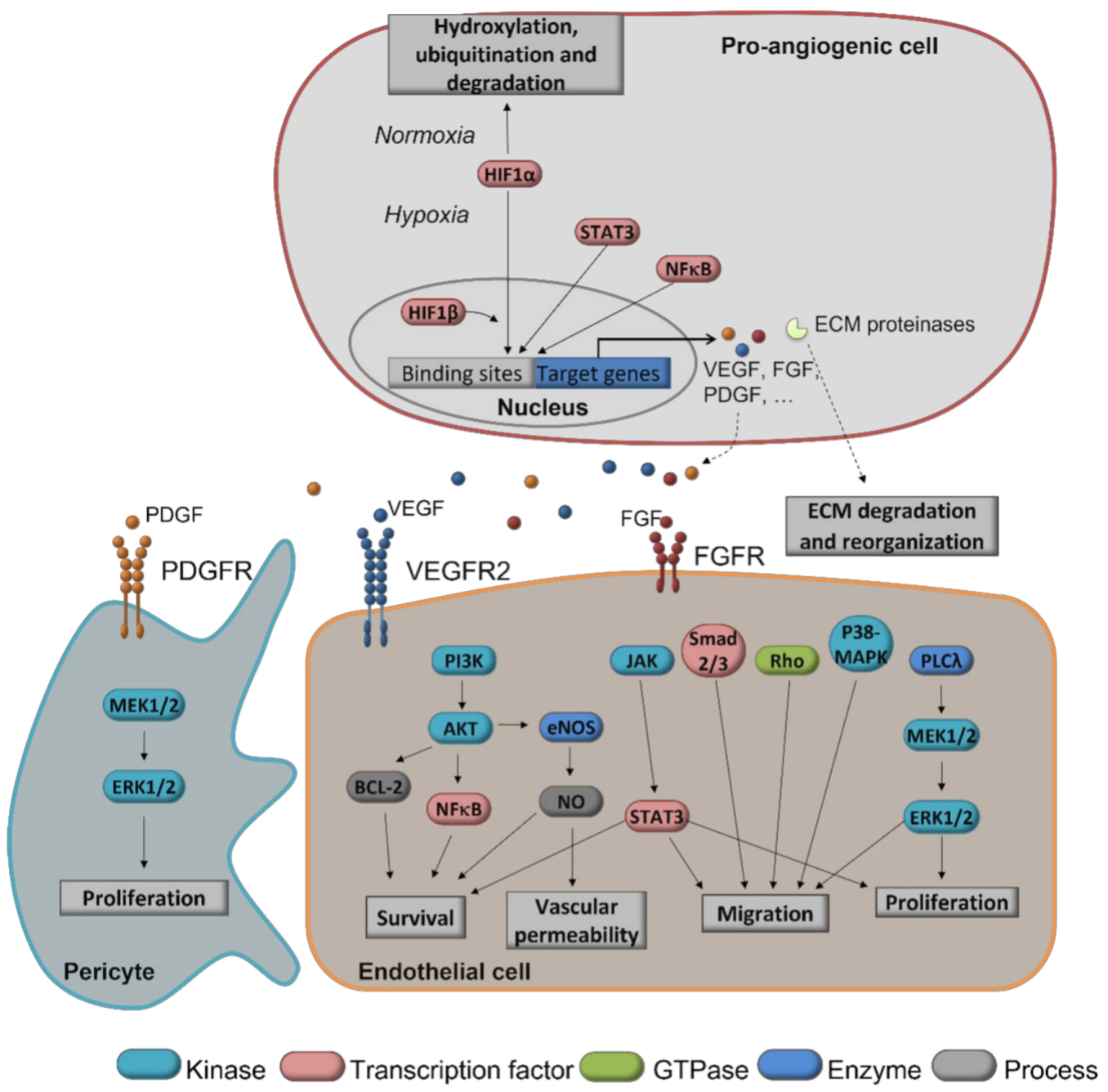

Figure 4. Summary of some of the most important signaling pathways, molecules, and processes involved in the angiogenic process. Proangiogenic cells (i.e., cancer cells) are a source of proangiogenic molecules, such as growth factors, for example, VEGF; cytokines; and ECM-degrading proteases, such as MMPs, that can be received by endothelial cells and pericytes, activating their differentiation, proliferation, survival, and migration to form new vessels. The proteases released by proangiogenic cells degrade the ECM to allow the migration of endothelial cells, releasing as well proangiogenic factors from ECM elements [41-44]. HIF-1 $\alpha / \beta$ : hypoxia-inducible factor 1-alpha/beta; STAT3: signal transducer and activator of transcription 3; NF- $\mathrm{kB}$ : nuclear factor kappa-light-chain-enhancer of activated B cells; VEGF(R): vascular endothelial growth factor (receptor); FGF(R): fibroblast growth factor (receptor); PDGF(R): platelet-derived growth factor (receptor); MEK1/2: mitogen-activated protein kinase kinase 1/2; ERK1/2: extracellular signal-regulated kinase 1/2; PI3K: phosphoinositide 3 kinase; eNOS: endothelial nitric oxide synthase; NO: nitric oxide; BCL-2: B-cell leukemia/lymphoma 2; JAK: Janus tyrosine kinase; Smad 2/3: mothers against decapentaplegic homolog 2; P38-MAPK: 38-kDa mitogen-activated protein kinase; PLC $\lambda$ : phospholipase C- $\lambda$.

Mechanistically, quercetin has been reported to interfere with different regulatory points of angiogenesis. In bovine aortic endothelial cells (BAEC), quercetin inhibited endothelial nitric oxide synthase (eNOS), an enzyme involved in the production of $\mathrm{NO}$ and, thus, promoting an increased vascular permeability [45] (Figure 4). It also induces cell cycle arrest in the early M-phase [46], interfering with mitosis and, thus, cellular replication. Cyclooxygenase-2 (COX-2) has been proposed as an additional target for quercetin in angiogenesis inhibition, related to extracellular matrix remodeling [45], thus suggesting a possible preventive use of this compound in COX-2-mediated diseases, such as breast cancer [47]. Additionally, this compound interferes with the mitogen-activated protein 
kinase (MAPK) pathway by inhibiting extracellular signal-regulated kinase (ERK) phosphorylation and suppresses the vascular endothelial growth factor 2 (VEGFR2)-regulated Ak strain, transforming (AKT)/mammalian target of rapamycin (mTOR)/P70S6K signaling in both endothelial cells [48] and tumor models [49] (Figure 4).

Additional data from in vivo models support the anticancer potential of quercetin [50-52], with a noteworthy interest in reversion of chemoresistance [52,53] and in nanoencapsulation of this compound $[52,54,55]$. Taken altogether, the pleiotropic regulatory actions exerted by quercetin in endothelial cells would explain the potent antiangiogenic effect of this compound. This, together with its direct antitumor effects, supports its potential role in cancer prevention. Provided these are promising experimental results, clinical trials are needed to clearly determine the efficacy of quercetin as a chemopreventive agent in cancer. Currently there is an active clinical trial based on the administration of quercetin as a dietary supplement for squamous cell carcinoma in patients with Fanconi anemia, whose results are expected to be released by 2023 [56].

\section{Myricetin}

Myricetin (Figure $3 b$ ) is a flavonol found in many vegetables, fruits, and herbs. The reported bioactivity of myricetin includes antioxidant, anti-inflammatory, and antitumor effects [57-60], which support its potential as a chemopreventive compound in cancer. As a matter of fact, it has been reported that myricetin can promote apoptosis in tumor cells via regulation of the B cell lymphoma 2 (Bcl-2) family of proteins, MAPK and Wnt/ $\beta$-catenin signaling pathways, disruption of reactive oxygen species (ROS) homeostasis, induction of endoplasmic reticulum stress, and DNA damage [61]. The antitumor potential of myricetin has also been related to its capacity to induce cell cycle arrest in cancer cells $[62,63]$. The particular role of myricetin as an inhibitor of angiogenesis has been studied in different cancer types $[64,65]$. In a mouse model of skin tumorigenesis, myricetin inhibited UVBinduced angiogenesis, decreasing VEGF, hypoxia-inducible factor 1 (HIF-1), MMP-9, and MMP-13 expression [65] (Figure 4). Additionally, in an assay in which endothelial cells migrate to form spontaneous tubular structures similar to vessels (Table 1), myricetin substantially suppressed tubular structure formation of human umbilical vein endothelial cells (HUVEC) stimulated by VEGF [66]. Myricetin also showed antiangiogenic effects on the in vivo CAM model [64] (Table 1). Interestingly, this compound also inhibited the PI3-K/AKT pathway in both tumor and endothelial cells $[64,65,67]$ (Figure 4). In line with the proapoptotic effect exhibited by myricetin on many tumor cell lines [62,68-77], this compound has also induced apoptosis in endothelial cells through a reactive oxygen species (ROS)-dependent mechanism [67]. Despite the fact that in vivo studies in rodents support the chemopreventive role of myricetin in different cancer models [78-85], there is no current clinical evidence of its preventive activity in cancer, nor are there any active clinical trials using this compound. Additional in vitro studies suggest a synergistic effect of myricetin with traditional anticancer drugs [86].

\section{Other Flavonols}

Kaempferol (Figure 3c) and fisetin (Figure 3d) are two bioactive flavonols found abundantly in vegetables, fruits, teas, and herbs, which exhibit interesting properties related to the chemoprevention of cancer. In addition to antioxidant and anti-inflammatory properties [87,88], kaempferol exhibits antitumor activity in different models of cancer [89-93]. The antitumor potential of kaempferol has been greatly assessed in breast cancer in both in vitro and in vivo models. This compound interferes with the pro-cancer activity of 17b-estradiol, bisphenol A, and the xenoestrogen triclosan [94-96], suggesting a preventive role of kaempferol in breast cancer. In this same line, kaempferol is also capable of arresting the cell cycle in breast cancer cells, promoting apoptosis via different pathways, and suppressing both migration and invasion $[93,97]$, among other effects, being a potential chemotherapeutic agent. In addition, a preventive role of kaempferol in several types of cancer has been proposed based on its properties to reduce tumor growth, inhibit metas- 
tasis, and induce apoptosis of tumoral cells in in vivo models [98-100]. Besides the direct effect on cancer cell growth and metastasis, kaempferol exhibits antiangiogenic activity by inhibiting VEGF expression in human ovarian cancer cells, an effect that seems to be mediated by both HIF-dependent and HIF-independent mechanisms [101]. The direct action on VEGF signaling was also reported in HUVEC when kaempferol inhibited angiogenesis by targeting VEGFR-2 and, consequently, downregulated the PI3K/AKT, MEK, and ERK pathways [102] (Figure 4). Additionally, downregulation of COX-2 expression and interference with the NF- $\mathrm{KB}$ pathway have been reported for kaempferol [45,65]. Moreover, this compound has been described to induce apoptosis in endothelial cells via the extrinsic pathway in an ROS-mediated p53/ATM/death receptor signaling mechanism [103].

The chemotherapeutic potential of fisetin in cancer and its multi-target mechanism of action leading to cell cycle arrest, apoptosis, and autophagic cell death have been reported in numerous in vitro and in vivo works [31,104-107]. Interestingly, this antioxidant flavonol shows antiangiogenic activity in vitro and in vivo, inhibiting endothelial survival, proliferation, migration, and tube formation [108,109] (Table 1). Although its inhibitory mechanism in tumoral angiogenesis is not completely described, fisetin has been reported to inhibit the expression of several molecules implicated in angiogenesis modulation and degradation of the extracellular matrix in both prostate carcinoma and lung carcinoma cell lines, as is the case of VEGF, eNOS, iNOS, MMP-2, and MMP-9 [108-110] (Figure 4). Interestingly, fisetin was proposed as an anticancer agent in combination with the traditional cisplatin to increase its cytotoxicity in human embryonal carcinoma NT2/D1 cells as a promising co-therapy, but, despite some rather interesting in vitro results (it was possible to reduce cisplatin concentration fourfold) [111], this approach has not reached the clinical practice yet.

\subsubsection{Isoflavones}

Consumption of soy food has been traditionally related to Asian culture, although, over the past 25 years, the majority of Western countries have markedly increased the use of soy products in their diet [112]. Despite the controversy regarding the effect of soy-derived compounds on cancer [113], research evidence suggests a beneficial role of soy food in health, especially associated with a decreased risk of developing certain types of cancer, such as prostate and breast cancer [114-116]. Isoflavones are polyphenolic compounds from the isoflavones subclass, included among the soybeans components and characterized for their capability to modulate estrogen receptor (ER) activity (phytoestrogenic activity) [117].

Genistein (Figure 3e) is one of the major isoflavones in soybeans, together with daidzein, biochanin $\mathrm{A}$, and others. This compound has been shown to inhibit cancer growth in vitro and in vivo [118-122], affecting cell cycle progression, apoptosis, angiogenesis, cell invasion, and metastasis. Mechanistically, genistein inhibits AKT, NF-KB, MMPs, and Bax/Bcl-2 signaling pathways, among others [119,123] (Figure 4). Interestingly, recent evidence supports the ability of genistein, together with other phytochemicals, such as curcumin, epigallocatechin-3-gallate (EGCG), or resveratrol, to eliminate cancer stem cell populations [124]. In addition, genistein is also a potent inhibitor of angiogenesis, and several mechanisms have been reported, both in endothelial and cancer cells, to be responsible for this activity, including the inhibition of protein tyrosine kinase activity and MAPK activation in VEGF-stimulated endothelial cells $[118,123,125]$ and the inhibition of HIF-1 in pancreatic carcinoma cells $[118,125,126]$ (Figure 4). Genistein downregulates the expression of VEGF, PDGF, and MMPs (Figure 4) and upregulates, on the contrary, the expression of endogenous angiogenesis inhibitors, such as plasminogen activator inhibitor-1, endostatin, angiostatin, and thrombospondin-1 [118,123,127-129].

Clinical trials have been performed to evaluate the possible preventive and therapeutic effect, two different applications [113], of genistein in different types of cancer. In a phase 2 clinical trial with patients with localized prostate cancer, short-term genistein intervention modulated the expression of several biomarkers related to prostate cancer prediction and progression, supporting a preventive role of genistein in this type of cancer [130]. 
In contrast, intervention with genistein in phase 2 clinical trials with bladder, pancreatic, and breast cancer patients failed to determine the chemopreventive activity of this compound, although the possibility of combining genistein treatment with other agents is a promising approach to exert a clinically effective preventive action [131-133]. In fact, in September 2019, genistein was shown to be safe and tolerable in combination with FOLFOX (a type of chemotherapy) or FOLFOX-Bevacizumab (chemotherapy plus an antiangiogenic therapy) to treat patients with metastatic colorectal cancer in a phase 1/2 pilot study, the reason why the investigators crave a larger clinical trial to accurately prove the efficacy of this treatment [134].

\subsubsection{Green Tea Polyphenols}

Green tea polyphenols have shown interesting chemopreventive and antiangiogenic properties. Indeed, regular consumption of green tea is associated with a reduced risk of some types of cancer $[135,136]$. One of these polyphenols is epigallocatechin-3-gallate (EGCG, belonging to the catechins family; Figure 3f), a potent antioxidant compound with pleiotropic activities. EGCG has been described as an anti-inflammatory, antiangiogenic, and antitumor compound that targets immune, endothelial, and tumor cells [137-141]. Two of its direct effects on tumor cells are modulation of cancer cell response to chemotherapy and induction of apoptosis [138]. The potent antiangiogenic activity of this compound can be mechanistically explained by its capability to regulate the VEGF/VEGFR axis at different levels: EGCG inhibits VEGF expression in cells, interferes with the binding of this ligand to VEGFR2, and reduces the activation of the receptor in endothelial cells [140-142] (Figure 4). In addition, other mechanisms have been proposed for the antiangiogenic effect of EGCG, pointing to the modulation of HIF- $1 \alpha$ and NF- $\mathrm{KB}$ pathways $[143,144]$ (Figure 4) and to the inhibition of endoglin/Smad1 signaling, an alternative proangiogenic pathway that can be activated in tumors to overcome the anti-VEGF therapy [145]. Interestingly, the chemopreventive potential of EGCG in oncologic diseases is reinforced by experimental results supporting the specificity of this compound on tumor-associated endothelial cells and endothelial progenitor cells in contrast to normal endothelial cells [146]. All the observed effects of this compound in cancer cells and tumor-associated processes make it feasible to point to EGCG as the main compound responsible for the beneficial activity of green tea in cancer prevention. Nevertheless, despite the promising chemopreventive properties of EGCG, it is not clear if this compound is able to prevent the initiation or progression of cancer, since clinical trials are still inconclusive or pending results. Differences in bioavailability, dosages, and potential side effects of EGCG are some of the aspects that make it difficult to come to a clear conclusion about its preventive potential [147-149], and further clinical studies are needed to verify this issue. Notably, a clinical trial performed in 2016 proved the safety of a decaffeinated catechin mixture containing $200 \mathrm{mg}$ EGCG to be further tested for prostate cancer prevention or other indications [150].

\subsubsection{Other Phenolic and Polyphenolic Compounds}

The list of plant-derived compounds with antitumor and antiangiogenic effects that are potentially active in cancer prevention is rather extensive and still increasing in length. In addition to the above-mentioned polyphenolic phytochemicals, there are some others that deserve special attention due to their high rates of consumption in many countries, especially in those with adherence to the Mediterranean diet [12]. This is the case for resveratrol (a polyphenolic compound found in grapes and red wine; Figure $3 \mathrm{~g}$ ) and hydroxytyrosol (a phenolic compound found in virgin olive oil; Figure 3h) [151,152].

The potential benefits of resveratrol in tumor prevention could be mediated by suppression of the activation of NF-кB [153] and the AKT/STAT3 signaling pathway [154]. Furthermore, modulation of the VEGF/VEGFR2 pathway through several axes (HIF-1 $\alpha$ and GSK3 $\beta / \beta$-catenin/TCF) seems to be the main mechanism of action of resveratrol in angiogenesis inhibition [155-161]. Despite the amount of available information from in vitro studies that indicate the potential therapeutic effects of resveratrol in cancer, the in vivo 
studies remain controversial [162-165] and the number of clinical trials focused on assessing its use as a chemopreventive agent are still very limited and showed nonconclusive results $[166,167]$. Additional efforts are needed to gain a deeper understanding of the targets and mechanisms of action of resveratrol and to clinically determine its health benefits.

Hydroxytyrosol, a bioactive compound constituent of virgin olive oil, exhibits multiple health-related properties [152]. Interestingly, our group found that this compound is a multitarget inhibitor of angiogenesis in vitro and in vivo [168,169], highlighting the potential of hydroxytyrosol and its synthetic derivatives $[170,171]$ in cancer prevention.

\subsection{Terpenes}

Terpenes are a large group of natural compounds derived from the isoprene structural unit, and they are classified attending to the number of isoprene units contained in the molecule (monoterpenes, diterpenes, triterpenes...). Many of these compounds are interesting in terms of biomedical research due to the pleiotropic biological activities exhibited, in addition to their easy availability, as they are components of many edible plants and fruits [172]. Natural terpenes, such as ursolic acid, celastrol, carnosol, carnosic acid, and kahweol, are good candidates for chemoprevention of cancer, showing promising antitumor and antiangiogenic activities.

\subsubsection{Ursolic Acid}

Ursolic acid (Figure 3i) is a pentacyclic triterpene present in the leaves of several plants used as herbal infusions or spices (rosemary, lemon balm, vervain, oregano, sage, thymus) and fruits (apples, cranberries) $[173,174]$. This phytochemical exhibits pleiotropic biological activity $[175,176]$, which probably derives from its capability to inhibit the NF- $\mathrm{kB}$ pathway and STAT3 activation, both in vitro and in vivo [177-183]. In addition, data from several groups, including ours, showed that ursolic acid has antiangiogenic properties, inhibiting key steps of angiogenesis in vitro [184-186]. However, a study reported that ursolic acid increased the expression of angiogenesis modulators, such as VEGF and FGF-2, in endothelial cells by a mechanism that implied the PI3K-AKT signaling pathway [187] (Figure 4). The antiangiogenic potential of ursolic acid has been confirmed in vivo in different murine animal models [180,184,188]. In addition, the bioavailability of ursolic acid after oral administration in mice, and toxicity, pharmacokinetics, and pharmacodynamics of liposomal ursolic acid in humans have been studied, showing promising results for its use in chemoprevention [189], although clinical trials are required to explore its efficacy and applicability to clinical practice.

\subsubsection{Kahweol}

Kahweol (Figure 3j) and cafestol are antioxidant diterpenes present in coffee beans and unfiltered coffee beverages. Their pharmacological interest is derived from their antiinflammatory and antitumor properties [190,191]. Among the antitumor effects, these diterpenes have shown antiangiogenic activity by inhibiting angiogenesis in vitro, ex vivo (mouse aortic ring assay), and in vivo (CAM and zebrafish intersegmental vessel models) (Table 1) through downregulation of the VEGFR2 levels and modulation of the VEGF pathway [192,193] (Figure 4), and targeting inflammatory molecules, such as COX-2 and monocyte chemoattractant protein-1 (MCP-1), in endothelial cells [194,195]. The interest in proposing kahweol and cafestol as potential chemopreventive compounds in cancer mainly relies on the high rate of consumption of coffee all around the globe.

\subsubsection{Other Terpenoids}

Celastrol (Figure 3k), carnosol (Figure 31), and carnosic acid (Figure 3m) represent good candidates for chemoprevention of cancer. In addition to its antioxidant, anti-inflammatory, and antitumor properties [196,197], the pentacyclic triterpenoid celastrol, present in the traditional Chinese herb Tripterygium wilfordii Hook, has been described as an antiangiogenic compound, modulating several pathways, including IKK/NF-kB (IкB kinase/NF-kB) 
pathway and HIF-1 $\alpha$ [197-201] (Figure 4). Carnosol and carnosic acid, active constituents of the rosemary herb, are also rather interesting diterpenes for cancer prevention, mainly due to their capability to inhibit angiogenesis in vitro and in vivo by a mechanism that implies the induction of apoptosis in endothelial cells [202,203].

\subsection{Anthraquinones}

Anthraquinones are an important group of natural and synthetic compounds derived from the molecule of anthraquinone. Important biologically active plant-contained anthraquinones have been described, showing interesting pharmacological activities, such as antitumor and anti-inflammatory effects [204]. Natural anthraquinones, such as emodin and aloe-emodin, are attractive compounds due to their potential chemopreventive properties in cancer [205].

\subsubsection{Emodin}

Emodin (Figure 3n) is a hydroxyanthraquinone found in molds, lichens, and edible plants, such as rhubarb. This compound has shown anticancer activity in different human cancer cell lines in vitro and in vivo [205-208], inducing apoptosis and inhibiting epithelial to mesenchymal transition (EMT) in colon cancer [209-211] and epithelial ovarian cancer cells [212]. Several reports indicated the antiangiogenic potential of emodin in the context of cancer [213]. This compound inhibited proliferation in endothelial cells by cell cycle arrest in the G2/M phase and induction of apoptosis, together with the inhibition of MMPs and VEGFR2 signaling. Furthermore, emodin has been described as a tyrosine kinase inhibitor, downregulating the phosphorylation of ERK 1/2, which contributes to its antiangiogenic effect [214-216] (Figure 4). In vivo experiments show the efficiency of emodin to inhibit angiogenesis in pancreatic cancer, coursing with the regulation of the TGF- $\beta$ /Smad pathway and angiogenesis-associated microRNAs miR-20b, miR-155, and miR-210 [217,218]. In breast cancer, emodin suppressed angiogenesis, downregulating Runx2 transcriptional activity [219]. Despite the promising results and the pleiotropic antitumor and antiangiogenic mechanism of action, the chemopreventive potential of emodin in cancer remains to be elucidated. Interestingly, a recent clinical study showed that administration of emodin attenuated the adverse effects caused by tamoxifen treatment via cyclin D1 and pERK upregulation in ER-positive breast cancer cell lines [220].

\subsubsection{Aloe-Emodin}

Aloe-emodin (Figure 3o), present in Aloe vera leaves, is a hydroxyanthraquinone with antitumor activity [205,221]. Our group reported the antiangiogenic potential of this compound based on its ability to inhibit urokinase secretion, as well as tubule formation of endothelial cells [222] (Table 1). The antiangiogenic role of aloe-emodin has been further supported by the observation that this compound downregulates MMP-2/9, RhoB, and VEGF in colon cancer cells, interfering with NF- $\kappa B$ binding activity [223] (Figure 4). Interestingly, a report that evaluated the antiangiogenic activity of aloe-emodin in the context of hypoxia-induced retinal angiogenesis showed that this compound interferes with the HIF$1 \alpha /$ VEGF pathway in vitro and in vivo [224] (Figure 4). However, the effect of aloe-emodin regarding angiogenesis should be further studied and clarified, since studies on in vivo models have related the wound-healing capacity of Aloe vera to proangiogenic effects [225].

\section{Concluding Remarks and Future Challenges}

The use of nontoxic plant-derived natural compounds as chemopreventive agents in cancer has become an attractive approach in the last years, since it represents a low-cost, easily accessible, and broad-spectrum alternative to conventional drugs. Additionally, the high number of bioactive compounds contained in plant foods that display antitumor and antiangiogenic effects in experimental models should prompt us to undoubtedly assess the feasibility of their use in cancer prevention. 
While broad experimental evidence obtained for these compounds clearly points to their capability to target events involved in cancer initiation and progress, their application to cancer prevention is still far away from being clinically established. For many of these compounds, clinical trials are still very limited, contradictory, inconclusive, or even inexistent, making it extremely difficult to clarify the level of efficacy of these compounds in cancer prevention, if any, as well as their preventive role on the population and the suitable regimens needed to achieve the desired health benefits. In this context, a significant effort is needed to improve the design of clinical trials, paying special attention to the target population, as well as to the pharmacokinetics and pharmacodynamics of the compounds. In terms of cancer treatment, however, the use of these compounds in combination with typical therapeutic agents comes as a rather interesting approach, as it would allow the reduction in the aggressiveness and side effects caused by these drugs, while also improving their effects.

Undoubtedly, a deeper understanding of the mechanism of action of the compounds in the context of the hallmarks of cancer is necessary, mainly attending to the pleiotropic character of their reported biological actions. In line with this, it is worth encouraging basic, translational, and clinical research to better integrate the available information to improve the outcome of clinical trials, and eventually determine the health benefits and efficacy of plant-derived bioactive compounds in the chemoprevention of cancer.

Author Contributions: Conceptualization, A.R.Q., B.M.-P. and M.Á.M.; investigation, A.D.M. and B.M.-P.; writing-original draft preparation, A.D.M. and B.M.-P.; writing-review and editing, A.D.M.; A.R.Q., B.M.-P. and M.Á.M.; supervision, A.R.Q., B.M.-P. and M.Á.M.; funding acquisition, A.R.Q., B.M.-P. and M.Á.M. All authors have read and agreed to the published version of the manuscript.

Funding: Supported by grants PID2019-105010RB-I00 (Spanish Ministry of Science, Innovation and Universities), UMA18-FEDERJA-220 and PY20_00257 (Andalusian Government and FEDER), and funds from group BIO 267 (Andalusian Government). The "CIBER de Enfermedades Raras" and "CIBER de Enfermedades Cardiovasculares" are an initiative from the ISCIII (Spain). The funders had no role in the study design, data collection and analysis, decision to publish, or preparation of the manuscript.

Conflicts of Interest: The authors declare no conflict of interest.

\section{References}

1. Sung, H.; Ferlay, J.; Siegel, R.L.; Laversanne, M.; Soerjomataram, I.; Jemal, A.; Bray, F. Global cancer statistics 2020: GLOBOCAN estimates of incidence and mortality worldwide for 36 cancers in 185 countries. CA Cancer J. Clin. 2021, 71, 209-249. [CrossRef] [PubMed]

2. Siegel, R.L.; Miller, K.D.; Fuchs, H.E.; Jemal, A. Cancer statistics, 2022. CA Cancer J. Clin. 2022, 72, 7-33. [CrossRef] [PubMed]

3. WHO World Health Organization. Cancer. Available online: https://www.who.int/news-room/fact-sheets/detail/cancer (accessed on 28 December 2021).

4. Barry, M.J.; Simmons, L.H. Prevention of Prostate Cancer Morbidity and Mortality: Primary Prevention and Early Detection. Med. Clin. N. Am. 2017, 101, 787-806. [CrossRef] [PubMed]

5. Cooperman, A.M.; Iskandar, M.E.; Wayne, M.G.; Steele, J.G. Prevention and Early Detection of Pancreatic Cancer. Surg. Clin. N. Am. 2018, 98, 1-12. [CrossRef] [PubMed]

6. New, M.; Keith, R. Early Detection and Chemoprevention of Lung Cancer. F1000Research 2018, 7, 61. [CrossRef] [PubMed]

7. Loomans-Kropp, H.A.; Umar, A. Cancer Prevention and Screening: The next Step in the Era of Precision Medicine. NPJ Precis. Oncol. 2019, 3, 3. [CrossRef]

8. Sporn, M.B. Approaches to Prevention of Epithelial Cancer during the Preneoplastic Period. Cancer Res. 1976, 36, 2699-2702.

9. Meyskens, F.L.; Mukhtar, H.; Rock, C.L.; Cuzick, J.; Kensler, T.W.; Yang, C.S.; Ramsey, S.D.; Lippman, S.M.; Alberts, D.S. Cancer Prevention: Obstacles, Challenges, and the Road Ahead. J. Natl. Cancer Inst. 2016, 108, djv309. [CrossRef]

10. Blackburn, E.H. Highlighting the Science of Cancer Prevention. Cancer Prev. Res. 2010, 3, 393. [CrossRef]

11. Albini, A.; Tosetti, F.; Li, V.W.; Noonan, D.M.; Li, W.W. Cancer Prevention by Targeting Angiogenesis. Nat. Rev. Clin. Oncol. 2012, 9, 498-509. [CrossRef]

12. Martínez-Poveda, B.; Torres-Vargas, J.A.; del Carmen Ocaña, M.; García-Caballero, M.; Medina, M.Á.; Quesada, A.R. The Mediterranean Diet, a Rich Source of Angiopreventive Compounds in Cancer. Nutrients 2019, 11, 2036. [CrossRef] [PubMed]

13. Hanahan, D.; Weinberg, R.A. The Hallmarks of Cancer. Cell 2000, 100, 57-70. [CrossRef] 
14. Hanahan, D.; Weinberg, R.A. Hallmarks of Cancer: The Next Generation. Cell 2011, 144, 646-674. [CrossRef] [PubMed]

15. Lugano, R.; Ramachandran, M.; Dimberg, A. Tumor Angiogenesis: Causes, Consequences, Challenges and Opportunities. Cell. Mol. Life Sci. 2020, 77, 1745-1770. [CrossRef] [PubMed]

16. Ribatti, D. Angiogenesis. In Brenner's Encyclopedia of Genetics, 2nd ed.; Maloy, S., Hughes, K., Eds.; Elsevier Inc.: Amsterdan, The Netherlands, 2013; pp. 130-132, ISBN 978-0-0809-6156-9.

17. Gerritsen, M.E. Angiogenesis. In Microcirculation, 2nd ed.; Tuma, R.F., Durán, W.N., Ley, K., Eds.; Elsevier Inc.: Amsterdan, The Netherlands, 2008; pp. 351-383, ISBN 978-0-1237-4530-9.

18. Wang, Z.; Dabrosin, C.; Yin, X.; Fuster, M.M.; Arreola, A.; Rathmell, W.K.; Generali, D.; Nagaraju, G.P.; El-Rayes, B.; Ribatti, D.; et al. Broad Targeting of Angiogenesis for Cancer Prevention and Therapy. Semin. Cancer Biol. 2015, 35, S224-S243. [CrossRef] [PubMed]

19. Hanahan, D. Hallmarks of Cancer: New Dimensions. Cancer Discov. 2022, 12, 31-46. [CrossRef] [PubMed]

20. Nowak-Sliwinska, P.; Alitalo, K.; Allen, E.; Anisimov, A.; Aplin, A.C.; Auerbach, R.; Augustin, H.G.; Bates, D.O.; van Beijnum, J.R.; Bender, R.H.F.; et al. Consensus Guidelines for the Use and Interpretation of Angiogenesis Assays. Angiogenesis 2018, 21, 425-532. [CrossRef]

21. Eccles, S.A.; Court, W.; Patterson, L. In Vitro Assays for Endothelial Cell Functions Required for Angiogenesis: Proliferation, Motility, Tubular Differentiation, and Matrix Proteolysis. In Angiogenesis Protocols; Martin, S., Hewett, P., Eds.; Humana Press: New York, NY, USA, 2016; Volume 1430, pp. 121-147.

22. Mosmann, T. Rapid Colorimetric Assay for Cellular Growth and Survival: Application to Proliferation and Cytotoxicity Assays. J. Immunol. Methods 1983, 65, 55-63. [CrossRef]

23. Quesada, A.R.; Barbacid, M.M.; Mira, E.; Fernández-Resa, P.; Márquez, G.; Aracil, M. Evaluation of Fluorometric and Zymographic Methods as Activity Assays for Stromelysins and Gelatinases. Clin. Exp. Metastasis 1997, 15, 26-32. [CrossRef]

24. Jin, J.; Hu, X.; Zhang, L.; Wang, J. Aorta Ring Assay. Bio-Protocol 2016, 6, e1856. [CrossRef]

25. Naik, M.; Brahma, P.; Dixit, M. A Cost-Effective and Efficient Chick Ex-Ovo Cam Assay Protocol to Assess Angiogenesis. Methods Protoc. 2018, 1, 19. [CrossRef]

26. Ribatti, D. The Chick Embryo Chorioallantoic Membrane (CAM). A Multifaceted Experimental Model. Mech. Dev. 2016, 141, 70-77. [CrossRef]

27. Lieschke, G.J.; Currie, P.D. Animal Models of Human Disease: Zebrafish Swim into View. Nat. Rev. Genet. 2007, 8, 353-367. [CrossRef] [PubMed]

28. Serbedzija, G.N.; Flynn, E.; Willett, C.E. Zebrafish Angiogenesis: A New Model for Drug Screening. Angiogenesis 1999, 3, $353-359$. [CrossRef] [PubMed]

29. Zon, L.I.; Peterson, R.T. In Vivo Drug Discovery in the Zebrafish. Nat. Rev. Drug Discov. 2005, 4, 35-44. [CrossRef] [PubMed]

30. García-Caballero, M.; Quesada, A.R.; Medina, M.Á.; Marí-Beffa, M. Fishing Anti(Lymph)Angiogenic Drugs with Zebrafish. Drug Discov. Today 2018, 23, 366-374. [CrossRef]

31. Kashyap, D.; Garg, V.K.; Tuli, H.S.; Yerer, M.B.; Sak, K.; Sharma, A.K.; Kumar, M.; Aggarwal, V.; Sandhu, S.S. Fisetin and Quercetin: Promising Flavonoids with Chemopreventive Potential. Biomolecules 2019, 9, 174. [CrossRef]

32. Murakami, A.; Ashida, H.; Terao, J. Multitargeted Cancer Prevention by Quercetin. Cancer Lett. 2008, 269, 315-325. [CrossRef]

33. Chien, S.-Y.; Wu, Y.-C.; Chung, J.-G.; Yang, J.-S.; Lu, H.-F.; Tsou, M.-F.; Wood, W.; Kuo, S.-J.; Chen, D.-R. Quercetin-Induced Apoptosis Acts through Mitochondrial- and Caspase-3-Dependent Pathways in Human Breast Cancer MDA-MB-231 Cells. Hum. Exp. Toxicol. 2009, 28, 493-503. [CrossRef]

34. Wang, K.; Liu, R.; Li, J.; Mao, J.; Lei, Y.; Wu, J.; Zeng, J.; Zhang, T.; Wu, H.; Chen, L.; et al. Quercetin Induces Protective Autophagy in Gastric Cancer Cells: Involvement of Akt-MTOR- and Hypoxia-Induced Factor 1 $\alpha$-Mediated Signaling. Autophagy 2011, 7, 966-978. [CrossRef]

35. Mouria, M.; Gukovskaya, A.S.; Jung, Y.; Buechler, P.; Hines, O.J.; Reber, H.A.; Pandol, S.J. Food-Derived Polyphenols Inhibit Pancreatic Cancer Growth through Mitochondrial Cytochrome C Release and Apoptosis. Int. J. Cancer 2002, 98, 761-769. [CrossRef] [PubMed]

36. McGill, C.M.; Brown, T.J.; Fisher, L.N.; Gustafson, S.J.; Dunlap, K.L.; Beck, A.J.; Toran, P.T.; Claxton, D.F.; Barth, B.M. Combinatorial Efficacy of Quercitin and Nanoliposomal Ceramide for Acute Myeloid Leukemia. Int. J. Biopharm. Sci. 2018, 1, 106. [CrossRef] [PubMed]

37. Vafadar, A.; Shabaninejad, Z.; Movahedpour, A.; Fallahi, F.; Taghavipour, M.; Ghasemi, Y.; Akbari, M.; Shafiee, A.; Hajighadimi, S.; Moradizarmehri, S.; et al. Quercetin and Cancer: New Insights into Its Therapeutic Effects on Ovarian Cancer Cells. Cell Biosci. 2020, 10, 1-17. [CrossRef] [PubMed]

38. Ward, A.B.; Mir, H.; Kapur, N.; Gales, D.N.; Carriere, P.P.; Singh, S. Quercetin Inhibits Prostate Cancer by Attenuating Cell Survival and Inhibiting Anti-Apoptotic Pathways. World J. Surg. Oncol. 2018, 16, 108. [CrossRef]

39. Najafi, M.; Tavakol, S.; Zarrabi, A.; Ashrafizadeh, M. Dual Role of Quercetin in Enhancing the Efficacy of Cisplatin in Chemotherapy and Protection against Its Side Effects: A Review. Arch. Physiol. Biochem. 2020, 10, 1-15. [CrossRef]

40. Tan, W.; Lin, L.; Li, M.; Zhang, Y.-X.; Tong, Y.; Xiao, D.; Ding, J. Quercetin, a Dietary-Derived Flavonoid, Possesses Antiangiogenic Potential. Eur. J. Pharmacol. 2003, 459, 255-262. [CrossRef]

41. Carmeliet, P.; Jain, R.K. Molecular Mechanisms and Clinical Applications of Angiogenesis. Nature 2011, 473, 298-307. [CrossRef] 
42. Chung, A.S.; Lee, J.; Ferrara, N. Targeting the Tumour Vasculature: Insights from Physiological Angiogenesis. Nat. Rev. Cancer 2010, 10, 505-514. [CrossRef]

43. Cross, M.J.; Claesson-Welsh, L. FGF and VEGF Function in Angiogenesis: Signalling Pathways, Biological Responses and Therapeutic Inhibition. Trends Pharmacol. Sci. 2001, 22, 201-207. [CrossRef]

44. Pezzuto, A.; Carico, E. Role of HIF-1 in Cancer Progression: Novel Insights. A Review. Curr. Mol. Med. 2018, 18, 343-351. [CrossRef]

45. García-Mediavilla, V.; Crespo, I.; Collado, P.S.; Esteller, A.; Sánchez-Campos, S.; Tuñón, M.J.; González-Gallego, J. The AntiInflammatory Flavones Quercetin and Kaempferol Cause Inhibition of Inducible Nitric Oxide Synthase, Cyclooxygenase-2 and Reactive C-Protein, and down-Regulation of the Nuclear Factor KappaB Pathway in Chang Liver Cells. Eur. J. Pharmacol. 2007, 557, 221-229. [CrossRef] [PubMed]

46. Jackson, S.J.T.; Venema, R.C. Quercetin Inhibits ENOS, Microtubule Polymerization, and Mitotic Progression in Bovine Aortic Endothelial Cells1. J. Nutr. 2006, 136, 1178-1184. [CrossRef] [PubMed]

47. Xiao, X.; Shi, D.; Liu, L.; Wang, J.; Xie, X.; Kang, T.; Deng, W. Quercetin Suppresses Cyclooxygenase-2 Expression and Angiogenesis through Inactivation of P300 Signaling. PLoS ONE 2011, 6, e22934. [CrossRef] [PubMed]

48. Pratheeshkumar, P.; Budhraja, A.; Son, Y.-O.; Wang, X.; Zhang, Z.; Ding, S.; Wang, L.; Hitron, A.; Lee, J.-C.; Xu, M.; et al. Quercetin Inhibits Angiogenesis Mediated Human Prostate Tumor Growth by Targeting VEGFR- 2 Regulated AKT/MTOR/P70S6K Signaling Pathways. PLoS ONE 2012, 7, e47516. [CrossRef] [PubMed]

49. Reyes-Farias, M.; Carrasco-Pozo, C. The Anti-Cancer Effect of Quercetin: Molecular Implications in Cancer Metabolism. Int. J. Mol. Sci. 2019, 20, 3177. [CrossRef]

50. Hashemzaei, M.; Far, A.D.; Yari, A.; Heravi, R.E.; Tabrizian, K.; Taghdisi, S.M.; Sadegh, S.E.; Tsarouhas, K.; Kouretas, D.; Tzanakakis, G.; et al. Anticancer and Apoptosis-Inducing Effects of Quercetin in Vitro and in Vivo. Oncol. Rep. 2017, 38, 819-828. [CrossRef]

51. Angst, E.; Park, J.L.; Moro, A.; Lu, Q.Y.; Lu, X.; Li, G.; King, J.; Chen, M.; Reber, H.A.; Go, V.L.W.; et al. The Flavonoid Quercetin Inhibits Pancreatic Cancer Growth in Vitro and in Vivo. Pancreas 2013, 42, 223-229. [CrossRef]

52. Fernández-Palanca, P.; Fondevila, F.; Méndez-Blanco, C.; Tuñón, M.J.; González-Gallego, J.; Mauriz, J.L. Antitumor Effects of Quercetin in Hepatocarcinoma In Vitro and In Vivo Models: A Systematic Review. Nutrients 2019, 11, 2875. [CrossRef]

53. Lu, X.; Yang, F.; Chen, D.; Zhao, Q.; Chen, D.; Ping, H.; Xing, N. Quercetin Reverses Docetaxel Resistance in Prostate Cancer via Androgen Receptor and PI3K/Akt Signaling Pathways. Int. J. Biol. Sci. 2020, 16, 1121-1134. [CrossRef]

54. Baksi, R.; Singh, D.P.; Borse, S.P.; Rana, R.; Sharma, V.; Nivsarkar, M. In Vitro and in Vivo Anticancer Efficacy Potential of Quercetin Loaded Polymeric Nanoparticles. Biomed. Pharmacother. 2018, 106, 1513-1526. [CrossRef]

55. Ravichandiran, V.; Masilamani, K.; Senthilnathan, B.; Maheshwaran, A.; Wong, T.W.; Roy, P. Quercetin-Decorated Curcumin Liposome Design for Cancer Therapy: In-Vitro and In-Vivo Studies. Curr. Drug Deliv. 2017, 14, 1053-1059. [CrossRef] [PubMed]

56. Children's Hospital Medical Center, Cincinnati. Quercetin Chemoprevention for Squamous Cell Carcinoma in Patients with Fanconi Anemia. Available online: https: / clinicaltrials.gov/ct2/show / study / NCT03476330?term=quercitin\&cond=cancer\& draw $=3 \&$ rank $=11$ (accessed on 28 December 2021).

57. Ribeiro de Lima, M.T.; Waffo-Téguo, P.; Teissedre, P.L.; Pujolas, A.; Vercauteren, J.; Cabanis, J.C.; Mérillon, J.M. Determination of Stilbenes (Trans-Astringin, Cis- and Trans-Piceid, and Cis- and Trans-Resveratrol) in Portuguese Wines. J. Agric. Food Chem. 1999, 47, 2666-2670. [CrossRef] [PubMed]

58. Sellappan, S.; Akoh, C.C. Flavonoids and Antioxidant Capacity of Georgia-Grown Vidalia Onions. J. Agric. Food Chem. 2002, 50, 5338-5342. [CrossRef] [PubMed]

59. Lee, K.W.; Kang, N.J.; Rogozin, E.A.; Kim, H.-G.; Cho, Y.Y.; Bode, A.M.; Lee, H.J.; Surh, Y.-J.; Bowden, G.T.; Dong, Z. Myricetin Is a Novel Natural Inhibitor of Neoplastic Cell Transformation and MEK1. Carcinogenesis 2007, 28, 1918-1927. [CrossRef]

60. Semwal, D.; Semwal, R.; Combrinck, S.; Viljoen, A. Myricetin: A Dietary Molecule with Diverse Biological Activities. Nutrients 2016, 8, 90. [CrossRef]

61. Jiang, M.; Zhu, M.; Wang, L.; Yu, S. Anti-Tumor Effects and Associated Molecular Mechanisms of Myricetin. Biomed. Pharmacother. 2019, 120, 109506. [CrossRef]

62. Feng, J.; Chen, X.; Wang, Y.; Du, Y.; Sun, Q.; Zang, W.; Zhao, G. Myricetin Inhibits Proliferation and Induces Apoptosis and Cell Cycle Arrest in Gastric Cancer Cells. Mol. Cell. Biochem. 2015, 408, 163-170. [CrossRef]

63. Zang, W.; Wang, T.; Wang, Y.; Li, M.; Xuan, X.; Ma, Y.; Du, Y.; Liu, K.; Dong, Z.; Zhao, G. Myricetin Exerts Anti-Proliferative, Anti-Invasive, and pro-Apoptotic Effects on Esophageal Carcinoma EC9706 and KYSE30 Cells via RSK2. Tumor Biol. 2014, 35, 12583-12592. [CrossRef]

64. Huang, H.; Chen, A.Y.; Rojanasakul, Y.; Ye, X.; Rankin, G.O.; Chen, Y.C. Dietary Compounds Galangin and Myricetin Suppress Ovarian Cancer Cell Angiogenesis. J. Funct. Foods 2015, 15, 464-475. [CrossRef]

65. Jung, S.K.; Lee, K.W.; Byun, S.; Lee, E.J.; Kim, J.E.; Bode, A.M.; Dong, Z.; Lee, H.J. Myricetin inhibits UVB-induced angiogenesis by regulating PI-3 kinase in vivo. Carcinogenesis 2010, 31, 911-917. [CrossRef]

66. Kim, J.D.; Liu, L.; Guo, W.; Meydani, M. Chemical Structure of Flavonols in Relation to Modulation of Angiogenesis and Immune-Endothelial Cell Adhesion. J. Nutr. Biochem. 2006, 17, 165-176. [CrossRef] [PubMed]

67. Kim, G.D. Myricetin Inhibits Angiogenesis by Inducing Apoptosis and Suppressing PI3K/Akt/MTOR Signaling in Endothelial Cells. J. Cancer Prev. 2017, 22, 219-227. [CrossRef] [PubMed] 
68. Ha, T.K.; Jung, I.; Kim, M.E.; Bae, S.K.; Lee, J.S. Anti-Cancer Activity of Myricetin against Human Papillary Thyroid Cancer Cells Involves Mitochondrial Dysfunction-Mediated Apoptosis. Biomed. Pharmacother. 2017, 91, 378-384. [CrossRef] [PubMed]

69. Pan, H.; Hu, Q.; Wang, J.; Liu, Z.; Wu, D.; Lu, W.; Huang, J. Myricetin Is a Novel Inhibitor of Human Inosine 5'-Monophosphate Dehydrogenase with Anti-Leukemia Activity. Biochem. Biophys. Res. Commun. 2016, 477, 915-922. [CrossRef]

70. Zheng, A.W.; Chen, Y.Q.; Zhao, L.Q.; Feng, J.G. Myricetin Induces Apoptosis and Enhances Chemosensitivity in Ovarian Cancer Cells. Oncol. Lett. 2017, 13, 4974-4978. [CrossRef]

71. Xu, Y.; Xie, Q.; Wu, S.; Yi, D.; Yu, Y.; Liu, S.; Li, S.; Li, Z. Myricetin Induces Apoptosis via Endoplasmic Reticulum Stress and DNA Double-Strand Breaks in Human Ovarian Cancer Cells. Mol. Med. Rep. 2016, 13, 2094-2100. [CrossRef]

72. Siegelin, M.D.; Gaiser, T.; Habel, A.; Siegelin, Y. Myricetin Sensitizes Malignant Glioma Cells to TRAIL-Mediated Apoptosis by down-Regulation of the Short Isoform of FLIP and Bcl-2. Cancer Lett. 2009, 283, 230-238. [CrossRef]

73. Jiao, D.; Zhang, X.D. Myricetin Suppresses P21-Activated Kinase 1 in Human Breast Cancer MCF-7 Cells through Downstream Signaling of the $\beta$-Catenin Pathway. Oncol. Rep. 2016, 36, 342-348. [CrossRef]

74. Knickle, A.; Fernando, W.; Greenshields, A.L.; Rupasinghe, H.P.V.; Hoskin, D.W. Myricetin-Induced Apoptosis of Triple-Negative Breast Cancer Cells Is Mediated by the Iron-Dependent Generation of Reactive Oxygen Species from Hydrogen Peroxide. Food Chem. Toxicol. 2018, 118, 154-167. [CrossRef]

75. Jo, S.; Ha, T.K.; Han, S.H.; Kim, M.E.; Jung, I.; Lee, H.W.; Bae, S.K.; Lee, J.S. Myricetin Induces Apoptosis of Human Anaplastic Thyroid Cancer Cells via Mitochondria Dysfunction. Anticancer Res. 2017, 37, 1705-1710. [CrossRef]

76. Park, H.; Park, S.; Bazer, F.W.; Lim, W.; Song, G. Myricetin Treatment Induces Apoptosis in Canine Osteosarcoma Cells by Inducing DNA Fragmentation, Disrupting Redox Homeostasis, and Mediating Loss of Mitochondrial Membrane Potential. J. Cell. Physiol. 2018, 233, 7457-7466. [CrossRef] [PubMed]

77. Yang, C.; Lim, W.; Bazer, F.W.; Song, G. Myricetin Suppresses Invasion and Promotes Cell Death in Human Placental Choriocarcinoma Cells through Induction of Oxidative Stress. Cancer Lett. 2017, 399, 10-19. [CrossRef] [PubMed]

78. Li, Y.; Cui, S.-X.; Sun, S.-Y.; Shi, W.-N.; Song, Z.-Y.; Wang, S.-Q.; Yu, X.-F.; Gao, Z.-H.; Qu, X.-J. Chemoprevention of Intestinal Tumorigenesis by the Natural Dietary Flavonoid Myricetin in APCMin/+ Mice. Oncotarget 2016, 7, 60446-60460. [CrossRef] [PubMed]

79. Zhang, M.J.; Su, H.; Yan, J.Y.; Li, N.; Song, Z.Y.; Wang, H.J.; Huo, L.G.; Wang, F.; Ji, W.S.; Qu, X.J.; et al. Chemopreventive Effect of Myricetin, a Natural Occurring Compound, on Colonic Chronic Inflammation and Inflammation-Driven Tumorigenesis in Mice. Biomed. Pharmacother. 2018, 97, 1131-1137. [CrossRef] [PubMed]

80. Ye, C.; Zhang, C.; Huang, H.; Yang, B.; Xiao, G.; Kong, D.; Tian, Q.; Song, Q.; Song, Y.; Tan, H.; et al. The Natural Compound Myricetin Effectively Represses the Malignant Progression of Prostate Cancer by Inhibiting PIM1 and Disrupting the PIM1/CXCR4 Interaction. Cell. Physiol. Biochem. 2018, 48, 1230-1244. [CrossRef]

81. Phillips, P.A.; Sangwan, V.; Borja-Cacho, D.; Dudeja, V.; Vickers, S.M.; Saluja, A.K. Myricetin Induces Pancreatic Cancer Cell Death via the Induction of Apoptosis and Inhibition of the Phosphatidylinositol 3-Kinase (PI3K) Signaling Pathway. Cancer Lett. 2011, 308, 181-188. [CrossRef]

82. Varela-Rodríguez, L.; Sánchez-Ramírez, B.; Hernández-Ramírez, V.I.; Varela-Rodríguez, H.; Castellanos-Mijangos, R.D.; GonzálezHorta, C.; Chávez-Munguía, B.; Talamás-Rohana, P. Effect of Gallic Acid and Myricetin on Ovarian Cancer Models: A Possible Alternative Antitumoral Treatment. BMC Complement. Med. Ther. 2020, 20, 110. [CrossRef]

83. Song, X.; Rao, H.; Guo, C.; Yang, B.; Ren, Y.; Wang, M.; Li, Y.; Cao, Z.; Pei, J. Myricetin Exhibit Selective Anti-Lymphoma Activity by Targeting BTK and Is Effective via Oral Administration in Vivo. Phytomedicine 2021, 93, 153802. [CrossRef]

84. Wang, G.; Wang, J.J.; Tang, X.J.; Du, L.; Li, F. In Vitro and in Vivo Evaluation of Functionalized Chitosan-Pluronic Micelles Loaded with Myricetin on Glioblastoma Cancer. Nanomedicine 2016, 12, 1263-1278. [CrossRef]

85. Li, M.; Zha, G.; Chen, R.; Chen, X.; Sun, Q.; Jiang, H. Anticancer Effects of Myricetin Derivatives in Non-Small Cell Lung Cancer in Vitro and in Vivo. Pharmacol. Res. Perspect. 2022, 10, e00905. [CrossRef]

86. Wang, L.; Feng, J.; Chen, X.; Guo, W.; Du, Y.; Wang, Y.; Zang, W.; Zhang, S.; Zhao, G. Myricetin Enhance Chemosensitivity of 5-Fluorouracil on Esophageal Carcinoma in Vitro and in Vivo. Cancer Cell Int. 2014, 14, 71. [CrossRef] [PubMed]

87. Ahn, M.-R.; Kunimasa, K.; Kumazawa, S.; Nakayama, T.; Kaji, K.; Uto, Y.; Hori, H.; Nagasawa, H.; Ohta, T. Correlation between Antiangiogenic Activity and Antioxidant Activity of Various Components from Propolis. Mol. Nutr. Food Res. 2009, 53, 643-651. [CrossRef] [PubMed]

88. Devi, K.P.; Malar, D.S.; Nabavi, S.F.; Sureda, A.; Xiao, J.; Nabavi, S.M.; Daglia, M. Kaempferol and Inflammation: From Chemistry to Medicine. Pharmacol. Res. 2015, 99, 1-10. [CrossRef] [PubMed]

89. Lee, J.; Kim, J.H. Kaempferol Inhibits Pancreatic Cancer Cell Growth and Migration through the Blockade of EGFR-Related Pathway in Vitro. PLoS ONE 2016, 11, e0155264. [CrossRef] [PubMed]

90. Kashafi, E.; Moradzadeh, M.; Mohamadkhani, A.; Erfanian, S. Kaempferol Increases Apoptosis in Human Cervical Cancer HeLa Cells via PI3K/AKT and Telomerase Pathways. Biomed. Pharmacother. 2017, 89, 573-577. [CrossRef]

91. Kapoor, S. Attenuating Effect of Kaempferol on Neoplastic Growth in Different Urological Malignancies. Biomed. Pharmacother. 2018, 104, 848. [CrossRef]

92. Han, X.; Liu, C.F.; Gao, N.; Zhao, J.; Xu, J. Kaempferol Suppresses Proliferation but Increases Apoptosis and Autophagy by Up-Regulating MicroRNA-340 in Human Lung Cancer Cells. Biomed. Pharmacother. 2018, 108, 809-816. [CrossRef] 
93. Li, S.; Yan, T.; Deng, R.; Jiang, X.; Xiong, H.; Wang, Y.; Yu, Q.; Wang, X.; Chen, C.; Zhu, Y. Low Dose of Kaempferol Suppresses the Migration and Invasion of Triple-Negative Breast Cancer Cells by Downregulating the Activities of RhoA and Rac1. OncoTargets Ther. 2017, 10, 4809-4819. [CrossRef]

94. Kim, S.-H.; Hwang, K.-A.; Choi, K.-C. Treatment with Kaempferol Suppresses Breast Cancer Cell Growth Caused by Estrogen and Triclosan in Cellular and Xenograft Breast Cancer Models. J. Nutr. Biochem. 2016, 28, 70-82. [CrossRef]

95. Lee, G.-A.; Choi, K.-C.; Hwang, K.-A. Kaempferol, a Phytoestrogen, Suppressed Triclosan-Induced Epithelial-Mesenchymal Transition and Metastatic-Related Behaviors of MCF-7 Breast Cancer Cells. Environ. Toxicol. Pharmacol. 2017, 49, 48-57. [CrossRef]

96. Lee, G.A.; Choi, K.C.; Hwang, K.A. Treatment with Phytoestrogens Reversed Triclosan and Bisphenol A-Induced Anti-Apoptosis in Breast Cancer Cells. Biomol. Ther. 2018, 26, 503-511. [CrossRef] [PubMed]

97. Zhu, L.; Xue, L. Kaempferol Suppresses Proliferation and Induces Cell Cycle Arrest, Apoptosis, and DNA Damage in Breast Cancer Cells. Oncol. Res. 2019, 27, 629-634. [CrossRef] [PubMed]

98. Hung, T.W.; Chen, P.N.; Wu, H.C.; Wu, S.W.; Tsai, P.Y.; Hsieh, Y.S.; Chang, H.R. Kaempferol Inhibits the Invasion and Migration of Renal Cancer Cells through the Downregulation of AKT and FAK Pathways. Int. J. Med. Sci. 2017, 14, 984-993. [CrossRef] [PubMed]

99. Dang, Q.; Song, W.; Xu, D.; Ma, Y.; Li, F.; Zeng, J.; Zhu, G.; Wang, X.; Chang, L.S.; He, D.; et al. Kaempferol Suppresses Bladder Cancer Tumor Growth by Inhibiting Cell Proliferation and Inducing Apoptosis. Mol. Carcinog. 2015, 54, 831-840. [CrossRef]

100. Song, H.; Bao, J.; Wei, Y.; Chen, Y.; Mao, X.; Li, J.; Yang, Z.; Xue, Y. Kaempferol Inhibits Gastric Cancer Tumor Growth: An in Vitro and in Vivo Study. Oncol. Rep. 2015, 33, 868-874. [CrossRef]

101. Luo, H.; Rankin, G.O.; Liu, L.; Daddysman, M.K.; Jiang, B.-H.; Chen, Y.C. Kaempferol Inhibits Angiogenesis and VEGF Expression through Both HIF Dependent and Independent Pathways in Human Ovarian Cancer Cells. Nutr. Cancer 2009, 61, 554-563. [CrossRef]

102. Chin, H.K.; Horng, C.T.; Liu, Y.S.; Lu, C.C.; Su, C.Y.; Chen, P.S.; Chiu, H.Y.; Tsai, F.J.; Shieh, P.C.; Yang, J.S. Kaempferol Inhibits Angiogenic Ability by Targeting VEGF Receptor-2 and Downregulating the PI3K/AKT, MEK and ERK Pathways in VEGF-Stimulated Human Umbilical Vein Endothelial Cells. Oncol. Rep. 2018, 39, 2351-2357. [CrossRef]

103. Lee, C.-F.; Yang, J.; Tsai, F.-J.; Chiang, N.-N.; Lu, C.; Huang, Y.-S.; Chen, C.; Chen, F.-A. Kaempferol Induces ATM/P53-Mediated Death Receptor and Mitochondrial Apoptosis in Human Umbilical Vein Endothelial Cells. Int. J. Oncol. 2016, 48, 2007-2014. [CrossRef]

104. Sundarraj, K.; Raghunath, A.; Perumal, E. A Review on the Chemotherapeutic Potential of Fisetin: In Vitro Evidences. Biomed. Pharmacother. 2018, 97, 928-940. [CrossRef]

105. Kashyap, D.; Sharma, A.; Sak, K.; Tuli, H.S.; Buttar, H.S.; Bishayee, A. Fisetin: A Bioactive Phytochemical with Potential for Cancer Prevention and Pharmacotherapy. Life Sci. 2018, 194, 75-87. [CrossRef]

106. Jia, S.; Xu, X.; Zhou, S.; Chen, Y.; Ding, G.; Cao, L. Fisetin Induces Autophagy in Pancreatic Cancer Cells via Endoplasmic Reticulum Stress- and Mitochondrial Stress-Dependent Pathways. Cell Death Dis. 2019, 10, 142. [CrossRef] [PubMed]

107. Xiao, Y.; Liu, Y.; Gao, Z.; Li, X.; Weng, M.; Shi, C.; Wang, C.; Sun, L. Fisetin Inhibits the Proliferation, Migration and Invasion of Pancreatic Cancer by Targeting PI3K/AKT/MTOR Signaling. Aging 2021, 13, 24753-24767. [CrossRef] [PubMed]

108. Bhat, T.A.; Nambiar, D.; Pal, A.; Agarwal, R.; Singh, R.P. Fisetin Inhibits Various Attributes of Angiogenesis in Vitro and in Vivo-Implications for Angioprevention. Carcinogenesis 2012, 33, 385-393. [CrossRef] [PubMed]

109. Park, J.H.; Jang, Y.J.; Choi, Y.J.; Jang, J.W.; Kim, J.H.; Rho, Y.K.; Kim, I.J.; Kim, H.J.; Leem, M.J.; Lee, S.T. Fisetin Inhibits Matrix Metalloproteinases and Reduces Tumor Cell Invasiveness and Endothelial Cell Tube Formation. Nutr. Cancer 2013, 65, 1192-1199. [CrossRef] [PubMed]

110. Chien, C.S.; Shen, K.H.; Huang, J.S.; Ko, S.C.; Shih, Y.W. Antimetastatic Potential of Fisetin Involves Inactivation of the PI3K/Akt and JNK Signaling Pathways with Downregulation of MMP-2/9 Expressions in Prostate Cancer PC-3 Cells. Mol. Cell. Biochem. 2010, 333, 169-180. [CrossRef] [PubMed]

111. Tripathi, R.; Samadder, T.; Gupta, S.; Surolia, A.; Shaha, C. Anticancer Activity of a Combination of Cisplatin and Fisetin in Embryonal Carcinoma Cells and Xenograft Tumors. Mol. Cancer Ther. 2011, 10, 255-268. [CrossRef] [PubMed]

112. Messina, M.; Rogero, M.M.; Fisberg, M.; Waitzberg, D. Health Impact of Childhood and Adolescent Soy Consumption. Nutr. Rev. 2017, 75, 500-515. [CrossRef]

113. Russo, M.; Russo, G.L.; Daglia, M.; Kasi, P.D.; Ravi, S.; Nabavi, S.F.; Nabavi, S.M. Understanding Genistein in Cancer: The "Good" and the "Bad" Effects: A Review. Food Chem. 2016, 196, 589-600. [CrossRef]

114. Mahmoud, A.M.; Yang, W.; Bosland, M.C. Soy Isoflavones and Prostate Cancer: A Review of Molecular Mechanisms. J. Steroid Biochem. Mol. Biol. 2014, 140, 116-132. [CrossRef]

115. Douglas, C.; Johnson, S.; Arjmandi, B. Soy and Its Isoflavones: The Truth Behind the Science in Breast Cancer. Anti-Cancer Agents Med. Chem. 2013, 13, 1178-1187. [CrossRef]

116. Zhao, T.T.; Jin, F.; Li, J.G.; Xu, Y.Y.; Dong, H.T.; Liu, Q.; Xing, P.; Zhu, G.L.; Xu, H.; Miao, Z.F. Dietary Isoflavones or Isoflavone-Rich Food Intake and Breast Cancer Risk: A Meta-Analysis of Prospective Cohort Studies. Clin. Nutr. 2019, 38, 136-145. [CrossRef] [PubMed]

117. Oseni, T.; Patel, R.; Pyle, J.; Jordan, V.C. Selective Estrogen Receptor Modulators and Phytoestrogens. Planta Med. 2008, 74, 1656-1665. [CrossRef] [PubMed] 
118. Varinska, L.; Gal, P.; Mojzisova, G.; Mirossay, L.; Mojzis, J. Soy and Breast Cancer: Focus on Angiogenesis. Int. J. Mol. Sci. 2015, 16, 11728-11749. [CrossRef] [PubMed]

119. Banerjee, S.; Li, Y.; Wang, Z.; Sarkar, F.H. Multi-Targeted Therapy of Cancer by Genistein. Cancer Lett. 2008, $269,226-242$. [CrossRef] [PubMed]

120. Hsiao, Y.C.; Peng, S.F.; Lai, K.C.; Liao, C.L.; Huang, Y.P.; Lin, C.C.; Lin, M.L.; Liu, K.C.; Tsai, C.C.; Ma, Y.S.; et al. Genistein Induces Apoptosis in Vitro and Has Antitumor Activity against Human Leukemia HL-60 Cancer Cell Xenograft Growth in Vivo. Environ. Toxicol. 2019, 34, 443-456. [CrossRef] [PubMed]

121. Tang, Q.; Ma, J.; Sun, J.; Yang, L.; Yang, F.; Zhang, W.; Li, R.; Wang, L.; Wang, Y.; Wang, H. Genistein and AG1024 Synergistically Increase the Radiosensitivity of Prostate Cancer Cells. Oncol. Rep. 2018, 40, 579-588. [CrossRef]

122. Chen, X.; Wu, Y.; Gu, J.; Liang, P.; Shen, M.; Xi, J.; Qin, J. Anti-Invasive Effect and Pharmacological Mechanism of Genistein against Colorectal Cancer. Biofactors 2020, 46, 620-628. [CrossRef]

123. Spagnuolo, C.; Russo, G.L.; Orhan, I.E.; Habtemariam, S.; Daglia, M.; Sureda, A.; Nabavi, S.F.; Devi, K.P.; Loizzo, M.R.; Tundis, R.; et al. Genistein and Cancer: Current Status, Challenges, and Future Directions. Adv. Nutr. 2015, 6, 408-419. [CrossRef]

124. Naujokat, C.; McKee, D.L. The "Big Five" Phytochemicals Targeting Cancer Stem Cells: Curcumin, EGCG, Sulforaphane, Resveratrol and Genistein. Curr. Med. Chem. 2020, 28, 4321-4342. [CrossRef]

125. Yu, X.; Zhu, J.; Mi, M.; Chen, W.; Pan, Q.; Wei, M. Anti-Angiogenic Genistein Inhibits VEGF-Induced Endothelial Cell Activation by Decreasing PTK Activity and MAPK Activation. Med. Oncol. 2012, 29, 349-357. [CrossRef]

126. Büchler, P.; Reber, H.A.; Büchler, M.W.; Friess, H.; Lavey, R.S.; Hines, O.J. Antiangiogenic Activity of Genistein in Pancreatic Carcinoma Cells Is Mediated by the Inhibition of Hypoxia-Inducible Factor-1 and the down-Regulation of VEGF Gene Expression. Cancer 2004, 100, 201-210. [CrossRef] [PubMed]

127. Sarkar, F.H.; Li, Y. Soy Isoflavones and Cancer Prevention. Cancer Investig. 2003, 21, 744-757. [CrossRef] [PubMed]

128. Kim, M.H. Flavonoids Inhibit VEGF/BFGF-Induced Angiogenesis in Vitro by Inhibiting the Matrix-Degrading Proteases. J. Cell. Biochem. 2003, 89, 529-538. [CrossRef] [PubMed]

129. Su, S.-J.; Yeh, T.-M.; Chuang, W.-J.; Ho, C.-L.; Chang, K.-L.; Cheng, H.-L.; Liu, H.-S.; Cheng, H.-L.; Hsu, P.-Y.; Chow, N.-H. The Novel Targets for Anti-Angiogenesis of Genistein on Human Cancer Cells. Biochem. Pharmacol. 2005, 69, 307-318. [CrossRef] [PubMed]

130. Lazarevic, B.; Hammarström, C.; Yang, J.; Ramberg, H.; Diep, L.M.; Karlsen, S.J.; Kucuk, O.; Saatcioglu, F.; Taskèn, K.A.; Svindland, A. The Effects of Short-Term Genistein Intervention on Prostate Biomarker Expression in Patients with Localised Prostate Cancer before Radical Prostatectomy. Br. J. Nutr. 2012, 108, 2138-2147. [CrossRef] [PubMed]

131. Messing, E.; Gee, J.R.; Saltzstein, D.R.; Kim, K.; DiSant'Agnese, A.; Kolesar, J.; Harris, L.; Faerber, A.; Havighurst, T.; Young, J.M.; et al. A Phase 2 Cancer Chemoprevention Biomarker Trial of Isoflavone G-2535 (Genistein) in Presurgical Bladder Cancer Patients. Cancer Prev. Res. 2013, 5, 621-630. [CrossRef] [PubMed]

132. El-Rayes, B.F.; Philip, P.A.; Sarkar, F.H.; Shields, A.F.; Ferris, A.M.; Hess, K.; Kaseb, A.O.; Javle, M.M.; Varadhachary, G.R.; Wolff, R.A.; et al. A Phase II Study of Isoflavones, Erlotinib, and Gemcitabine in Advanced Pancreatic Cancer. Investig. New Drugs 2011, 29, 694-699. [CrossRef]

133. Khan, S.A.; Chatterton, R.T.; Michel, N.; Bryk, M.; Lee, O.; Ivancic, D.; Heinz, R.; Zalles, C.M.; Helenowski, I.; Jovanovic, B.; et al Soy Isoflavone Supplementation for Breast Cancer Risk Reduction: A Randomized Phase II Trial. Cancer Prev. Res. 2012, 5, 309-319. [CrossRef]

134. Pintova, S.; Dharmupari, S.; Moshier, E.; Zubizarreta, N.; Ang, C.; Holcombe, R.F. Genistein Combined with FOLFOX or FOLFOX-Bevacizumab for the Treatment of Metastatic Colorectal Cancer: Phase I/II Pilot Study. Cancer Chemother. Pharmacol. 2019, 84, 591-598. [CrossRef]

135. Kim, T.L.; Jeong, G.H.; Yang, J.W.; Lee, K.H.; Kronbichler, A.; van der Vliet, H.J.; Grosso, G.; Galvano, F.; Aune, D.; Kim, J.Y.; et al. Tea Consumption and Risk of Cancer: An Umbrella Review and Meta-Analysis of Observational Studies. Adv. Nutr. 2020, 11, 1437-1452. [CrossRef]

136. Zhang, Y.F.; Xu, Q.; Lu, J.; Wang, P.; Zhang, H.W.; Zhou, L.; Ma, X.Q.; Zhou, Y.H. Tea Consumption and the Incidence of Cancer: A Systematic Review and Meta-Analysis of Prospective Observational Studies. Eur. J. Cancer Prev. 2015, 24, 353-362. [CrossRef] [PubMed]

137. Melgarejo, E.; Medina, M.Á.; Sánchez-Jiménez, F.; Urdiales, J.L. Targeting of Histamine Producing Cells by EGCG: A Green Dart against Inflammation? J. Physiol. Biochem. 2010, 66, 265-270. [CrossRef] [PubMed]

138. Singh, B.N.; Shankar, S.; Srivastava, R.K. Green Tea Catechin, Epigallocatechin-3-Gallate (EGCG): Mechanisms, Perspectives and Clinical Applications. Biochem. Pharmacol. 2011, 82, 1807-1821. [CrossRef] [PubMed]

139. Luo, K.W.; Wei, C.; Lung, W.Y.; Wei, X.Y.; Cheng, B.H.; Cai, Z.M.; Huang, W.R. EGCG Inhibited Bladder Cancer SW780 Cell Proliferation and Migration Both in Vitro and in Vivo via Down-Regulation of NF-KB and MMP-9. J. Nutr. Biochem. 2017, 41, 56-64. [CrossRef]

140. Neuhaus, T.; Pabst, S.; Stier, S.; Weber, A.A.; Schrör, K.; Sachinidis, A.; Vetter, H.; Ko, Y.D. Inhibition of the Vascular-Endothelial Growth Factor-Induced Intracellular Signaling and Mitogenesis of Human Endothelial Cells by Epigallocatechin-3 Gallate. Eur. J. Pharmacol. 2004, 483, 223-227. [CrossRef] 
141. Moyle, C.W.A.; Cerezo, A.B.; Winterbone, M.S.; Hollands, W.J.; Alexeev, Y.; Needs, P.W.; Kroon, P.A. Potent Inhibition of VEGFR-2 Activation by Tight Binding of Green Tea Epigallocatechin Gallate and Apple Procyanidins to VEGF: Relevance to Angiogenesis. Mol. Nutr. Food Res. 2015, 59, 401-412. [CrossRef]

142. Rashidi, B.; Malekzadeh, M.; Goodarzi, M.; Masoudifar, A.; Mirzaei, H. Green Tea and Its Anti-Angiogenesis Effects. Biomed. Pharmacother. 2017, 89, 949-956. [CrossRef]

143. Li, X.; Feng, Y.; Liu, J.; Feng, X.; Zhou, K.; Tang, X. Epigallocatechin-3-Gallate Inhibits IGF-I-Stimulated Lung Cancer Angiogenesis through Downregulation of HIF-1a and VEGF Expression. Mol. Nutr. Food Res. 2013, 6, 169-178. [CrossRef]

144. Gu, J.-W.; Makey, K.L.; Tucker, K.B.; Chinchar, E.; Mao, X.; Pei, I.; Thomas, E.Y.; Miele, L. EGCG, a Major Green Tea Catechin Suppresses Breast Tumor Angiogenesis and Growth via Inhibiting the Activation of HIF-1 $\alpha$ and NFkB, and VEGF Expression. Vasc. Cell 2013, 5, 9. [CrossRef]

145. Chen, C.Y.; Lin, Y.J.; Wang, C.C.N.; Lan, Y.H.; Lan, S.J.; Sheu, M.J. Epigallocatechin-3-Gallate Inhibits Tumor Angiogenesis: Involvement of Endoglin/Smad1 Signaling in Human Umbilical Vein Endothelium Cells. Biomed. Pharmacother. 2019, $120,109491$. [CrossRef]

146. Ohga, N.; Hida, K.; Hida, Y.; Muraki, C.; Tsuchiya, K.; Matsuda, K.; Ohiro, Y.; Totsuka, Y.; Shindoh, M. Inhibitory Effects of Epigallocatechin-3 Gallate, a Polyphenol in Green Tea, on Tumor-Associated Endothelial Cells and Endothelial Progenitor Cells. Cancer Sci. 2009, 100, 1963-1970. [CrossRef] [PubMed]

147. Mereles, D.; Hunstein, W. Epigallocatechin-3-Gallate (EGCG) for Clinical Trials: More Pitfalls than Promises? Int. J. Mol. Sci. 2011, 12, 5592-5603. [CrossRef] [PubMed]

148. Khan, N.; Adhami, V.M.; Mukhtar, H. Apoptosis by Dietary Agents for Prevention and Treatment of Prostate Cancer. Endocr. Relat. Cancer 2010, 17, R39-R52. [CrossRef] [PubMed]

149. Iriti, M.; Varoni, E.M. Chemopreventive Potential of Flavonoids in Oral Squamous Cell Carcinoma in Human Studies. Nutrients 2013, 5, 2564-2576. [CrossRef]

150. Kumar, N.B.; Pow-Sang, J.; Spiess, P.E.; Park, J.; Salup, R.; Williams, C.R.; Parnes, H.; Schell, M.J. Randomized, Placebo-Controlled Trial Evaluating the Safety of One-Year Administration of Green Tea Catechins. Oncotarget 2016, 7, 70794-70802. [CrossRef]

151. Gescher, A.; Steward, W.P.; Brown, K. Resveratrol in the Management of Human Cancer: How Strong Is the Clinical Evidence? Ann. N. Y. Acad. Sci. 2013, 1290, 12-20. [CrossRef]

152. Granados-Principal, S.; Quiles, J.L.; Ramirez-Tortosa, C.L.; Sanchez-Rovira, P.; Ramirez-Tortosa, M.C. Hydroxytyrosol: From Laboratory Investigations to Future Clinical Trials. Nutr. Rev. 2010, 68, 191-206. [CrossRef]

153. Yang, X.; Li, X.; Ren, J. From French Paradox to Cancer Treatment: Anti-Cancer Activities and Mechanisms of Resveratrol. Anti-Cancer Agents Med. Chem. 2014, 14, 806-825. [CrossRef]

154. Li, D.; Wang, G.; Jin, G.; Yao, K.; Zhao, Z.; Bie, L.; Guo, Y.; Li, N.; Deng, W.; Chen, X.; et al. Resveratrol Suppresses Colon Cancer Growth by Targeting the AKT/STAT3 Signaling Pathway. Int. J. Mol. Med. 2019, 43, 630-640. [CrossRef]

155. Park, S.Y.; Jeong, K.J.; Lee, J.; Yoon, D.S.; Choi, W.S.; Kim, Y.K.; Han, J.W.; Kim, Y.M.; Kim, B.K.; Lee, H.Y. Hypoxia Enhances LPA-Induced HIF-1 $\alpha$ and VEGF Expression: Their Inhibition by Resveratrol. Cancer Lett. 2007, 258, 63-69. [CrossRef]

156. Yu, H.-B.; Zhang, H.-F.; Zhang, X.; Li, D.-Y.; Xue, H.-Z.; Pan, C.-E.; Zhao, S.-H. Resveratrol Inhibits VEGF Expression of Human Hepatocellular Carcinoma Cells through a NF-Kappa B-Mediated Mechanism. Hepato-Gastroenterol. 2010, 57, 1241-1246.

157. Trapp, V.; Parmakhtiar, B.; Papazian, V.; Willmott, L.; Fruehauf, J.P. Anti-Angiogenic Effects of Resveratrol Mediated by Decreased VEGF and Increased TSP1 Expression in Melanoma-Endothelial Cell Co-Culture. Angiogenesis 2010, 13, 305-315. [CrossRef] [PubMed]

158. Igura, K.; Ohta, T.; Kuroda, Y.; Kaji, K. Resveratrol and Quercetin Inhibit Angiogenesis in Vitro. Cancer Lett. 2001, 171, 11-16. [CrossRef]

159. Bråkenhielm, E.; Cao, R.; Cao, Y. Suppression of Angiogenesis, Tumor Growth, and Wound Healing by Resveratrol, a Natural Compound in Red Wine and Grapes. FASEB J. 2001, 15, 1798-1800. [CrossRef] [PubMed]

160. Wang, H.; Zhou, H.; Zou, Y.; Liu, Q.; Guo, C.; Gao, G.; Shao, C.; Gong, Y. Resveratrol Modulates Angiogenesis through the GSK3 $\beta$ / $\beta$-Catenin/TCF-Dependent Pathway in Human Endothelial Cells. Biochem. Pharmacol. 2010, 80, 1386-1395. [CrossRef]

161. Kasiotis, K.M.; Pratsinis, H.; Kletsas, D.; Haroutounian, S.A. Resveratrol and Related Stilbenes: Their Anti-Aging and AntiAngiogenic Properties. Food Chem. Toxicol. 2013, 61, 112-120. [CrossRef]

162. Carter, L.G.; D’Orazio, J.A.; Pearson, K.J. Resveratrol and Cancer: Focus on in Vivo Evidence. Endocr. Relat. Cancer 2014, 21, R209-R225. [CrossRef]

163. Ko, J.H.; Sethi, G.; Um, J.Y.; Shanmugam, M.K.; Arfuso, F.; Kumar, A.P.; Bishayee, A.; Ahn, K.S. The Role of Resveratrol in Cancer Therapy. Int. J. Mol. Sci. 2017, 18, 2589. [CrossRef]

164. Sinha, D.; Sarkar, N.; Biswas, J.; Bishayee, A. Resveratrol for Breast Cancer Prevention and Therapy: Preclinical Evidence and Molecular Mechanisms. Semin. Cancer Biol. 2016, 40, 209-232. [CrossRef]

165. Yousef, M.; Vlachogiannis, I.A.; Tsiani, E. Effects of Resveratrol against Lung Cancer: In Vitro and In Vivo Studies. Nutrients 2017, 9, 1231. [CrossRef]

166. Singh, C.K.; Ndiaye, M.A.; Ahmad, N. Resveratrol and Cancer: Challenges for Clinical Translation. Biochim. Biophys. Acta 2015, 1852, 1178-1185. [CrossRef] [PubMed]

167. Novelle, M.G.; Wahl, D.; Diéguez, C.; Bernier, M.; de Cabo, R. Resveratrol Supplementation: Where Are We Now and Where Should We Go? Ageing Res. Rev. 2015, 21, 1-15. [CrossRef] [PubMed] 
168. Fortes, C.; García-Vilas, J.A.; Quesada, A.R.; Medina, M.Á. Evaluation of the Anti-Angiogenic Potential of Hydroxytyrosol and Tyrosol, Two Bio-Active Phenolic Compounds of Extra Virgin Olive Oil, in Endothelial Cell Cultures. Food Chem. 2012, 134, 134-140. [CrossRef]

169. García-Vilas, J.A.; Quesada, A.R.; Medina, M.Á. Hydroxytyrosol Targets Extracellular Matrix Remodeling by Endothelial Cells and Inhibits Both Ex Vivo and in Vivo Angiogenesis. Food Chem. 2017, 221, 1741-1746. [CrossRef] [PubMed]

170. López-Jiménez, A.; Gallardo, E.; Espartero, J.L.; Madrona, A.; Quesada, A.R.; Medina, M.Á. Comparison of the Anti-Angiogenic Potential of Hydroxytyrosol and Five Derivatives. Food Funct. 2018, 9, 4310-4316. [CrossRef]

171. Marrero, A.D.; Castilla, L.; Espartero, J.L.; Madrona, A.; R. Quesada, A.; Medina, M.Á.; Martínez-Poveda, B. A Comparative Study of the Antiangiogenic Activity of Hydroxytyrosyl Alkyl Ethers. Food Chem. 2020, 333, 127476. [CrossRef] [PubMed]

172. Kiyama, R. Estrogenic Terpenes and Terpenoids: Pathways, Functions and Applications. Eur. J. Pharmacol. 2017, 815, 405-415. [CrossRef]

173. Jäger, S.; Trojan, H.; Kopp, T.; Laszczyk, M.N.; Scheffler, A. Pentacyclic Triterpene Distribution in Various Plants-Rich Sources for a New Group of Multi-Potent Plant Extracts. Molecules 2009, 14, 2016-2031. [CrossRef]

174. Kondo, M.; Mackinnon, S.L.; Craft, C.C.; Matchett, M.D.; Hurta, R.A.R.; Neto, C.C. Ursolic Acid and Its Esters: Occurrence in Cranberries and Other Vaccinium Fruit and Effects on Matrix Metalloproteinase Activity in DU145 Prostate Tumor Cells. J. Sci. Food Agric. 2011, 91, 789-796. [CrossRef]

175. Kashyap, D.; Tuli, H.S.; Sharma, A.K. Ursolic Acid (UA): A Metabolite with Promising Therapeutic Potential. Life Sci. 2016, 146, 201-213. [CrossRef]

176. Cargnin, S.T.; Gnoatto, S.B. Ursolic Acid from Apple Pomace and Traditional Plants: A Valuable Triterpenoid with Functional Properties. Food Chem. 2017, 220, 477-489. [CrossRef] [PubMed]

177. Shishodia, S.; Majumdar, S.; Banerjee, S.; Aggarwal, B.B. Ursolic Acid Inhibits Nuclear Factor- K B Activation Induced by Carcinogenic Agents through Suppression of IкB $\alpha$ Kinase and P65 Phosphorylation: Correlation with Down-Regulation of Cyclooxygenase 2, Matrix Metalloproteinase 9, and Cyclin D1. Cancer Res. 2003, 63, 4375-4383. [PubMed]

178. Li, J.; Liang, X.; Yang, X. Ursolic Acid Inhibits Growth and Induces Apoptosis in Gemcitabine-Resistant Human Pancreatic Cancer via the JNK and PI3K/Akt/NF-KB Pathways. Oncol. Rep. 2012, 28, 501-510. [CrossRef] [PubMed]

179. Shanmugam, M.K.; Ong, T.H.; Kumar, A.P.; Lun, C.K.; Ho, P.C.; Wong, P.T.H.; Hui, K.M.; Sethi, G. Ursolic Acid Inhibits the Initiation, Progression of Prostate Cancer and Prolongs the Survival of TRAMP Mice by Modulating Pro-Inflammatory Pathways. PLoS ONE 2012, 7, e32476. [CrossRef]

180. Prasad, S.; Yadav, V.R.; Sung, B.; Reuter, S.; Kannappan, R.; Deorukhkar, A.; Diagaradjane, P.; Wei, C.; Baladandayuthapani, V.; Krishnan, S.; et al. Ursolic Acid Inhibits Growth and Metastasis of Human, Colorectal Cancer in an Orthotopic Nude Mouse Model by Targeting Multiple Cell Signaling Pathways: Chemosensitization with Capecitabine. Clin. Cancer Res. 2012, 18, 4942-4953. [CrossRef]

181. Prasad, S.; Yadav, V.R.; Sung, B.; Gupta, S.C.; Tyagi, A.K.; Aggarwal, B.B. Ursolic Acid Inhibits the Growth of Human Pancreatic Cancer and Enhances the Antitumor Potential of Gemcitabine in an Orthotopic Mouse Model through Suppression of the Inflammatory Microenvironment. Oncotarget 2016, 7, 13182-13196. [CrossRef]

182. Ovesná, Z.; Vachálková, A.; Horváthová, K.; Tóthová, D. Pentacyclic Triterpenoic Acids: New Chemoprotective Compounds. Neoplasma 2004, 51, 327-333.

183. Wang, W.; Zhao, C.; Jou, D.; Lü, J.; Zhang, C.; Lin, L.I.; Lin, J. Ursolic Acid Inhibits the Growth of Colon Cancer-Initiating Cells by Targeting STAT3. Anticancer Res. 2013, 33, 4279-4284.

184. Lin, J.; Chen, Y.; Wei, L.; Hong, Z.; Sferra, T.J.; Peng, J. Ursolic Acid Inhibits Colorectal Cancer Angiogenesis through Suppression of Multiple Signaling Pathways. Int. J. Oncol. 2013, 43, 1666-1674. [CrossRef]

185. Lin, C.C.; Huang, C.Y.; Mong, M.C.; Chan, C.Y.; Yin, M.C. Antiangiogenic Potential of Three Triterpenic Acids in Human Liver Cancer Cells. J. Agric. Food Chem. 2011, 59, 755-762. [CrossRef]

186. Cárdenas, C.; Quesada, A.R.; Medina, M.Á. Effects of Ursolic Acid on Different Steps of the Angiogenic Process. Biochem. Biophys. Res. Commun. 2004, 320, 402-408. [CrossRef] [PubMed]

187. Kiran, M.S.; Viji, R.I.; Sameer Kumar, V.B.; Sudhakaran, P.R. Modulation of Angiogenic Factors by Ursolic Acid. Biochem. Biophys. Res. Commun. 2008, 371, 556-560. [CrossRef] [PubMed]

188. Saraswati, S.; Agrawal, S.S.; Alhaider, A.A. Ursolic Acid Inhibits Tumor Angiogenesis and Induces Apoptosis through Mitochondrial-Dependent Pathway in Ehrlich Ascites Carcinoma Tumor. Chem. Biol. Interact. 2013, 206, 153-165. [CrossRef] [PubMed]

189. Shanmugam, M.K.; Dai, X.; Kumar, A.P.; Tan, B.K.H.; Sethi, G.; Bishayee, A. Ursolic Acid in Cancer Prevention and Treatment: Molecular Targets, Pharmacokinetics and Clinical Studies. Biochem. Pharmacol. 2013, 85, 1579-1587. [CrossRef]

190. Cárdenas, C.; Quesada, A.R.; Medina, M.Á. Insights on the Antitumor Effects of Kahweol on Human Breast Cancer: Decreased Survival and Increased Production of Reactive Oxygen Species and Cytotoxicity. Biochem. Biophys. Res. Commun. 2014, 447, 452-458. [CrossRef]

191. Ren, Y.; Wang, C.; Xu, J.; Wang, S. Cafestol and Kahweol: A Review on Their Bioactivities and Pharmacological Properties. Int. J. Mol. Sci. 2019, 20, 4238. [CrossRef]

192. Wang, S.; Yoon, Y.C.; Sung, M.J.; Hur, H.J.; Park, J.H. Antiangiogenic Properties of Cafestol, a Coffee Diterpene, in Human Umbilical Vein Endothelial Cells. Biochem. Biophys. Res. Commun. 2012, 421,567-571. [CrossRef] 
193. Moeenfard, M.; Cortez, A.; Machado, V.; Costa, R.; Luís, C.; Coelho, P.; Soares, R.; Alves, A.; Borges, N.; Santos, A. Anti-Angiogenic Properties of Cafestol and Kahweol Palmitate Diterpene Esters. J. Cell. Biochem. 2016, 117, 2748-2756. [CrossRef]

194. Cárdenas, C.; Quesada, A.R.; Medina, M.Á. Anti-Angiogenic and Anti-Inflammatory Properties of Kahweol, a Coffee Diterpene. PLoS ONE 2011, 6, e23407. [CrossRef]

195. Hao, W.R.; Sung, L.C.; Chen, C.C.; Chen, P.Y.; Cheng, T.H.; Chao, H.H.; Liu, J.C.; Chen, J.J. Cafestol Inhibits Cyclic-Strain-Induced Interleukin-8, Intercellular Adhesion Molecule-1, and Monocyte Chemoattractant Protein-1 Production in Vascular Endothelial Cells. Oxidative Med. Cell. Longev. 2018, 2018, 7861518. [CrossRef]

196. Cascão, R.; Fonseca, J.E.; Moita, L.F. Celastrol: A Spectrum of Treatment Opportunities in Chronic Diseases. Front. Med. 2017, 4, 69. [CrossRef] [PubMed]

197. Kashyap, D.; Sharma, A.; Tuli, H.S.; Sak, K.; Mukherjee, T.; Bishayee, A. Molecular Targets of Celastrol in Cancer: Recent Trends and Advancements. Crit. Rev. Oncol./Hematol. 2018, 128, 70-81. [CrossRef] [PubMed]

198. Huang, Y.; Zhou, Y.; Fan, Y.; Zhou, D. Celastrol Inhibits the Growth of Human Glioma Xenografts in Nude Mice through Suppressing VEGFR Expression. Cancer Lett. 2008, 264, 101-106. [CrossRef] [PubMed]

199. Pang, X.; Yi, Z.; Zhang, J.; Lu, B.; Sung, B.; Qu, W.; Aggarwal, B.B.; Liu, M. Celastrol Suppresses Angiogenesis-Mediated Tumor Growth through Inhibition of AKT/Mammalian Target of Rapamycin Pathway. Cancer Res. 2010, 70, 1951-1959. [CrossRef]

200. Huang, L.; Zhang, Z.; Zhang, S.; Ren, J.; Zhang, R.; Zeng, H.; Li, Q.; Wu, G. Inhibitory Action of Celastrol on Hypoxia-Mediated Angiogenesis and Metastasis via the HIF-1 $\alpha$ Pathway. Int. J. Mol. Med. 2011, 27, 407-415. [CrossRef]

201. Ni, H.; Zhao, W.; Kong, X.; Li, H.; Ouyang, J. Celastrol Inhibits Lipopolysaccharide-Induced Angiogenesis by Suppressing TLR4-Triggered Nuclear Factor-Kappa B Activation. Acta Haematol. 2014, 131, 102-111. [CrossRef]

202. López-Jiménez, A.; García-Caballero, M.; Medina, M.Á.; Quesada, A.R. Anti-Angiogenic Properties of Carnosol and Carnosic Acid, Two Major Dietary Compounds from Rosemary. Eur. J. Nutr. 2013, 52, 85-95. [CrossRef]

203. Kashyap, D.; Kumar, G.; Sharma, A.; Sak, K.; Tuli, H.S.; Mukherjee, T.K. Mechanistic Insight into Carnosol-Mediated Pharmacological Effects: Recent Trends and Advancements. Life Sci. 2017, 169, 27-36. [CrossRef]

204. Malik, E.M.; Müller, C.E. Anthraquinones As Pharmacological Tools and Drugs. Med. Res. Rev. 2016, 36, 705-748. [CrossRef]

205. Sánchez, M.; González-Burgos, E.; Iglesias, I.; Gómez-Serranillos, M.P. Pharmacological Update Properties of Aloe Vera and Its Major Active Constituents. Molecules 2020, 25, 1324. [CrossRef]

206. Hsu, S.C.; Chung, J.G. Anticancer Potential of Emodin. BioMedicine 2012, 2, 108-116. [CrossRef]

207. Liu, A.; Chen, H.; Wei, W.; Ye, S.; Liao, W.; Gong, J.; Jiang, Z.; Wang, L.; Lin, S. Antiproliferative and Antimetastatic Effects of Emodin on Human Pancreatic Cancer. Oncol. Rep. 2011, 26, 81-89. [CrossRef]

208. Ok, S.; Kim, S.-M.; Kim, C.; Nam, D.; Shim, B.S.; Kim, S.-H.; Ahn, K.S.; Choi, S.-H.; Ahn, K.S. Emodin Inhibits Invasion and Migration of Prostate and Lung Cancer Cells by Downregulating the Expression of Chemokine Receptor CXCR4. Immunopharmacol. Immunotoxicol. 2012, 34, 768-778. [CrossRef]

209. Lee, K.H.; Lee, M.S.; Cha, E.Y.; Sul, J.Y.; Lee, J.S.; Kim, J.S.; Park, J.B.; Kim, J.Y. Inhibitory Effect of Emodin on Fatty Acid Synthase, Colon Cancer Proliferation and Apoptosis. Mol. Med. Rep. 2017, 15, 2163-2173. [CrossRef] [PubMed]

210. Gu, J.; Cui, C.; Yang, L.; Wang, L.; Jiang, X. Emodin Inhibits Colon Cancer Cell Invasion and Migration by Suppressing Epithelialmesenchymal Transition via the Wnt/ $\beta$-Catenin Pathway. Oncol. Res. 2018, 27, 193-202. [CrossRef] [PubMed]

211. Saunders, I.T.; Mir, H.; Kapur, N.; Singh, S. Emodin Inhibits Colon Cancer by Altering BCL-2 Family Proteins and Cell Survival Pathways. Cancer Cell Int. 2019, 19, 98. [CrossRef] [PubMed]

212. Hu, C.; Dong, T.; Li, R.; Lu, J.; Wei, X.; Liu, P. Emodin Inhibits Epithelial to Mesenchymal Transition in Epithelial Ovarian Cancer Cells by Regulation of GSK-3 $\beta$ / $\beta$-Catenin/ZEB1 Signaling Pathway. Oncol. Rep. 2016, 35, 2027-2034. [CrossRef] [PubMed]

213. Wei, W.T.; Lin, S.Z.; Liu, D.L.; Wang, Z.H. The Distinct Mechanisms of the Antitumor Activity of Emodin in Different Types of Cancer (Review). Oncol. Rep. 2013, 30, 2555-2562. [CrossRef] [PubMed]

214. Srinivas, G.; Babykutty, S.; Sathiadevan, P.P.; Srinivas, P. Molecular Mechanism of Emodin Action: Transition from Laxative Ingredient to an Antitumor Agent. Med. Res. Rev. 2007, 27, 591-608. [CrossRef] [PubMed]

215. Kaneshiro, T.; Morioka, T.; Inamine, M.; Kinjo, T.; Arakaki, J.; Chiba, I.; Sunagawa, N.; Suzui, M.; Yoshimi, N. Anthraquinone Derivative Emodin Inhibits Tumor-Associated Angiogenesis through Inhibition of Extracellular Signal-Regulated Kinase 1/2 Phosphorylation. Eur. J. Pharmacol. 2006, 553, 46-53. [CrossRef] [PubMed]

216. Sun, Y.; Wang, X.; Zhou, Q.; Lu, Y.; Zhang, H.; Chen, Q.; Zhao, M.; Su, S. Inhibitory Effect of Emodin on Migration, Invasion and Metastasis of Human Breast Cancer MDA-MB-231 Cells in Vitro and in Vivo. Oncol. Rep. 2015, 33, 338-346. [CrossRef]

217. Lin, S.-Z.; Wei, W.-T.; Chen, H.; Chen, K.-J.; Tong, H.-F.; Wang, Z.-H.; Ni, Z.-L.; Liu, H.-B.; Guo, H.-C.; Liu, D.-L. Antitumor Activity of Emodin against Pancreatic Cancer Depends on Its Dual Role: Promotion of Apoptosis and Suppression of Angiogenesis. PLoS ONE 2012, 7, e42146. [CrossRef] [PubMed]

218. Lin, S.Z.; Xu, J.B.; Ji, X.; Chen, H.; Xu, H.T.; Hu, P.; Chen, L.; Guo, J.Q.; Chen, M.Y.; Lu, D.; et al. Emodin Inhibits Angiogenesis in Pancreatic Cancer by Regulating the Transforming Growth Factor- $\beta$ /Drosophila Mothers against Decapentaplegic Pathway and Angiogenesis-Associated MicroRNAs. Mol. Med. Rep. 2015, 12, 5865-5871. [CrossRef] [PubMed]

219. Ma, J.; Lu, H.; Wang, S.; Chen, B.; Liu, Z.; Ke, X.; Liu, T.; Fu, J. The Anthraquinone Derivative Emodin Inhibits Angiogenesis and Metastasis through Downregulating Runx2 Activity in Breast Cancer. Int. J. Oncol. 2015, 46, 1619-1628. [CrossRef] [PubMed]

220. Kim, Y.G.; Park, Y.H.; Yang, E.Y.; Park, W.S.; Park, K.S. Inhibition of Tamoxifen's Therapeutic Effects by Emodin in Estrogen Receptor-Positive Breast Cancer Cell Lines. Ann. Surg. Treat. Res. 2019, 97, 230. [CrossRef] 
221. Pecere, T.; Gazzola, M.V.; Mucignat, C.; Tumors, N.; Parolin, C.; Vecchia, F.D.; Cavaggioni, A.; Basso, G.; Diaspro, A.; Salvato, B.; et al. Aloe-Emodin Is a New Type of Anticancer Agent with Selective Activity against Neuroectodermal Tumors. Cancer Res. 2000, 60, 2800-2804.

222. Cárdenas, C.; Quesada, A.R.; Medina, M.Á. Evaluation of the Anti-Angiogenic Effect of Aloe-Emodin. Cell. Mol. Life Sci. 2006, 63, 3083-3089. [CrossRef]

223. Suboj, P.; Babykutty, S.; Valiyaparambil Gopi, D.R.; Nair, R.S.; Srinivas, P.; Gopala, S. Aloe Emodin Inhibits Colon Cancer Cell Migration/Angiogenesis by Downregulating MMP-2/9, RhoB and VEGF via Reduced DNA Binding Activity of NF-KB. Eur. J. Pharm. Sci. 2012, 45, 581-591. [CrossRef]

224. Wu, J.M.; Ke, X.; Wang, W.; Zhang, H.; Ma, N.; Fu, W.; Zhao, M.; Gao, X.; Hao, X.; Zhang, Z. Aloe-Emodin Suppresses Hypoxia-Induced Retinal Angiogenesis via Inhibition of HIF-1 $\alpha$ /VEGF Pathway. Int. J. Biol. Sci. 2016, 12, 1363-1371. [CrossRef]

225. Lin, L.X.; Wang, P.; Wang, Y.T.; Huang, Y.; Jiang, L.; Wang, X.M. Aloe Vera and Vitis Vinifera Improve Wound Healing in an in Vivo Rat Burn Wound Model. Mol. Med. Rep. 2016, 13, 1070-1076. [CrossRef] 